Article

\title{
Prediction Models for the Mechanical Properties of Self-Compacting Concrete with Recycled Rubber and Silica Fume
}

\author{
Robert Bušić $^{1, *}$, Mirta Benšić ${ }^{2}$, Ivana Miličević ${ }^{1}$ (D) and Kristina Strukar ${ }^{1}$ \\ 1 Faculty of Civil Engineering and Architecture Osijek, Josip Juraj Strossmayer University of Osijek, \\ Vladimira Preloga 3, HR-31000 Osijek, Croatia; ivana.milicevic@gfos.hr (I.M.); kstrukar@gfos.hr (K.S.) \\ 2 Department of Mathematics, Josip Juraj Strossmayer University of Osijek, Gajev trg 6, \\ HR-31000 Osijek, Croatia; mirta@mathos.hr \\ * Correspondence: rbusic@gfos.hr
}

Received: 21 March 2020; Accepted: 10 April 2020; Published: 12 April 2020

\begin{abstract}
The paper aims to investigate the influence of waste tire rubber and silica fume on the fresh and hardened properties of self-compacting concrete (SCC) and to design multivariate regression models for the prediction of the mechanical properties of self-compacting rubberized concrete (SCRC). For this purpose, 21 concrete mixtures were designed. Crumb rubber derived from end-of-life tires (grain size $0.5-3.5 \mathrm{~mm}$ ) was replaced fine aggregate by $0 \%, 5 \%, 10 \%, 15 \%, 20 \%, 25 \%$, and $30 \%$ of total aggregate volume. Silica fume was replaced cement by $0 \%, 5 \%$, and $10 \%$ of the total cement mass. The optimal replacement level of both materials was investigated in relation to the values of the fresh properties and mechanical properties of self-compacting concrete. Tests on fresh and hardened self-compacting concrete were performed according to the relevant European standards. Furthermore, models for predicting the values of the compressive strength, modulus of elasticity, and flexural strength of SCRC were designed and verified with the experimental results of 12 other studies. According to the obtained results, mixtures with up to $15 \%$ of recycled rubber and $5 \%$ of silica fume, with 28 days compressive strength above $30 \mathrm{MPa}$, were found to be optimal mixtures for the potential future investigation of reinforced self-compacting rubberized concrete structural elements.
\end{abstract}

Keywords: self-compacting rubberized concrete (SCRC); waste tire rubber; silica fume; fresh and hardened SCRC properties; multivariate regression models

\section{Introduction}

After almost two decades, the idea to combine concrete with waste recycled tire rubber as an aggregate replacement is still the subject of a large number of experimental investigations. To date, a considerable number of authors investigated traditional concrete with recycled rubber derived from end-of-life tires (ELTs), and it is known that this type of environmentally friendly concrete has been used in non-structural concrete elements such as traffic noise barriers, sidewalks, and sport fields [1-4] mainly because the implementation of the waste tire rubber in concrete reduces the value of the compressive strength and modulus of elasticity of concrete [5-13]. On the other hand, a smaller number of authors investigated the self-compacting rubberized concrete (SCRC) in terms of concrete used for structural elements $[8,14-16]$. The advantages of using recycled rubber as a substitute material for natural fine and/or coarse aggregate in concrete such as increased ductility, reduced total concrete mass, improved dynamic properties [17-22], increased freeze-thaw resistance [23-27], increased cracking resistance [16,28], increased fracture energy [22,29,30], and concrete resistance to tensile stresses [30] provide sufficient reasons to continue experimental research and laboratory work on reinforced concrete elements and system (columns, beams, frames) with a certain percentage of recycled rubber powder 
and granules as a replacement material for fine or coarse aggregate. From the previous experimental work $[6,9,31,32]$ and literature reviews [33-35], it can be concluded that when replacing natural fine aggregate with rubber granules, the negative impact on mechanical characteristics of the material is still lesser compared to the negative impact of replacing natural coarse or natural fine and coarse aggregate with rubber aggregate.

The mechanical properties of SCRC can vary significantly depending on mixture design, material properties, supplementary cementitious materials (SCMs) used in experiment, type and size of recycled rubber, etc. The use of crumb rubber (CR) and SCMs in structural self-compacting concrete (SCC) is a promising method to decrease the negative impacts of waste on the environment and to reduce cement consumption. Before structural application and full-scale experiments in the laboratory, the SCC mixture design needs to be determined, due to the desired concrete strength. In addition to the requirements for the mechanical resistance and stability of the structure, the replacement level of CR and SCMs should also be selected respecting economic criteria, since the replacement of the natural fine aggregate with crumb rubber negatively effects on the designed fresh and hardened state properties of SCC. Hence, the use of mineral and chemical additives, such as different types of SCMs and superplasticizers, are obligatory to preserve concrete design properties. SCMs are mostly used to enhance the mechanical and durability properties of SCC. Recently, there are many studies on the effect of silica fume (SLF) and other SCMs on the fresh and hardened properties of highly flowable cementitious composites. Some of these studies investigated the mutual effects of SLF and other SCMs, such as fly ash, metakaolin (MK), and ground granulated blast-furnace slag (GGBFS) on the mechanical and durability properties [36-40] of highly flowable cementitious composites, while other studies investigated the individual effect of SLF on SCC properties [41-43]. Considering SCRC, in several experiments where the mutual effects of SLF and other SCMs were investigated, an improvement in mechanical properties was reported [6,44]. Furthermore, AbdelAleem et al. [5] investigated how a 10\% replacement level of cement with SLF influences SCRC mechanical properties. However, there are no studies on the combination effect of different replacement levels of both CR and SLF, without any other SCMs, on the fresh and hardened properties of SCC.

There are two main research objectives of the present study. First, (i) to examine the coupling effect of different replacement levels of both SLF and CR on the mechanical properties of SCC. For this purpose, 21 SCC mixtures were made, with different replacement levels of natural fine aggregate $(0 \%, 5 \%, 10 \%, 15 \%, 20 \%, 25 \%, 30 \%$ of total aggregate volume) with CR and cement $(0 \%, 5 \%$, and $10 \%$ by mass) with SLF. Second, (ii) to develop prediction models for the mechanical properties of SCC with CR and SLF, i.e., compressive strength, modulus of elasticity, and flexural strength. In Sections 2 and 3, the materials, methods, and test results are given. Furthermore, appropriate models are presented and verified in Section 3 for each observed mechanical property by using two independent variables: the amount of CR and SLF.

\section{Materials and Methods}

\subsection{Materials Used for Experiment}

SCC mixtures were designed in accordance with the parameters given by the European Guidelines for self-compacting concrete [45]. Ordinary Portland cement CEM I 42.5R from the local cement factory Našice, Croatia, with a specific gravity of $3.17 \mathrm{~g} / \mathrm{cm}^{3}$ and Blaine fineness of $4378 \mathrm{~cm}^{2} / \mathrm{g}$, which complies with the requirement of European Standards EN 197-1:2002 [46], was used in this study. The chemical properties of cement used in experiment are given in Table 1. The chemical and physical properties are in accordance with the limit values given in EN 197-1:2002 [46]. Silica fume obtained from Pocking, Germany with the specific gravity of $2.2 \mathrm{~g} / \mathrm{cm}^{3}$ and Blaine fineness of $20.5 \mathrm{~m}^{2} / \mathrm{g}$, which is in accordance with the European Standards EN 13263-1:2009 [47], was used in concrete mixtures as a mineral additive and supplementary cementitious material. The properties of the silica fume used in the experimental study are given in Table 2. Tap water from the public water supply system, which is in accordance 
with EN 1008:2002 [48], was used as the mixing water of mixture. In order to achieve the desirable properties of self-compacting concrete in fresh state, i.e., flowability, viscosity, and passing ability classes, superplasticizer (SP) Energy FM500 and viscosity-modifying admixture (VMA) Premadd Stabilisator $\mathrm{X}$ were used in the production of SCC as chemical admixtures. The dosage of SP and VMA given by producers are between $1-2 \%$ and $0.2-0.3 \%$ of the total binder amount by weight, respectively. Both chemical admixtures are in compliance with EN 934-1:2008 [49] and EN 934-2:2012 [50]. If it was necessary, the amount of superplasticizer and viscosity-modifying admixture was adjusted during the mixing procedure, primarily to achieve acceptable slump flow values. The main properties of the chemical admixtures are given in Table 3, which was provided by the manufacturer.

Table 1. Chemical properties of cement.

\begin{tabular}{cccc}
\hline Chemical Compound & \% of Mass & Chemical Compound & \% of Mass \\
\hline $\mathrm{CaO}$ & 61.24 & $\mathrm{MgO}$ & 2.84 \\
$\mathrm{SiO}_{2}$ & 21.33 & $\mathrm{MnO}$ & 0.14 \\
$\mathrm{Al}_{2} \mathrm{O}_{3}$ & 5.69 & $\mathrm{~K}_{2} \mathrm{O}$ & 0.74 \\
$\mathrm{Fe}_{2} \mathrm{O}_{3}$ & 2.27 & $\mathrm{Na}_{2} \mathrm{O}$ & 0.37 \\
$\mathrm{SO}_{3}$ & 3.52 & $\mathrm{LOI}$ & 1.52 \\
\hline
\end{tabular}

Table 2. Physical and chemical properties of silica fume.

\begin{tabular}{ccccccc}
\hline Color and Form & Main Active Component & Density $\left(\mathrm{g} / \mathrm{cm}^{3}\right)$ & $\mathrm{SiO}_{2}(\%)$ & $\begin{array}{c}\text { Specific Surface } \\
\left(\mathrm{m}^{2} / \mathrm{g}\right)\end{array}$ & $\begin{array}{c}\text { Primary Graining } \\
(\mu \mathrm{m})\end{array}$ & $\begin{array}{c}\text { Maximum Consumption } \\
(\% \text { of cement weight) }\end{array}$ \\
\hline Gray powder & Amorphous $\mathrm{SiO}_{2}$ & 2.2 & $96 \pm 1.5$ & 20.5 & $0.1-0.3$ & 11 \\
\hline
\end{tabular}

Table 3. Properties of superplasticizer (SP) and viscosity-modifying admixture (VMA).

\begin{tabular}{ccc}
\hline Property & SP-Energy FM500 & VMA-Premadd Stabilisator $\mathbf{X}$ \\
\hline Shape & liquid & liquid \\
Color & amber & white, milky \\
Density $(\mathrm{kg} / \mathrm{L})$ & $1.08 \pm 0.02$ & $1.04 \pm 0.02$ \\
$\mathrm{pH} \mathrm{Value}$ & $3.5 \pm 2.0$ & $7.0 \pm 2.0$ \\
\hline
\end{tabular}

Dolomite powder, size $<0.063 \mathrm{~mm}$, from a local quarry, with a specific gravity of $2.97 \mathrm{~g} / \mathrm{cm}^{3}$ and Blaine fineness of $5206 \mathrm{~cm}^{2} / \mathrm{g}$ was used as a filler. The density of cement, silica fume, and dolomite powder was tested according to ASTM C188-16:2011 [51].

Natural sand and crushed stone with nominal sizes of $0-2,0-4,4-8$, and $8-16 \mathrm{~mm}$ with specific gravities of $2.58,2.79,2.88$, and $2.88 \mathrm{~g} / \mathrm{cm}^{3}$ were used as a fine (FA) and coarse aggregate (CA). Rubber aggregate, size $0.5-3.5 \mathrm{~mm}$, obtained by the mechanical grinding of local waste tires, was used as a fine aggregate replacement $(0-4 \mathrm{~mm})$. The specific gravity of rubber aggregate, i.e., crumb rubber $(\mathrm{CR})$, was $1.05 \mathrm{~g} / \mathrm{cm}^{3}$. The appearance of silica fume and crumb rubber is shown in Figure 1. The size grading of the fine aggregate, coarse aggregate, and crumb rubber, obtained through the sieve analysis according to EN 933-1:2012 [52], is shown in Figure 2. 


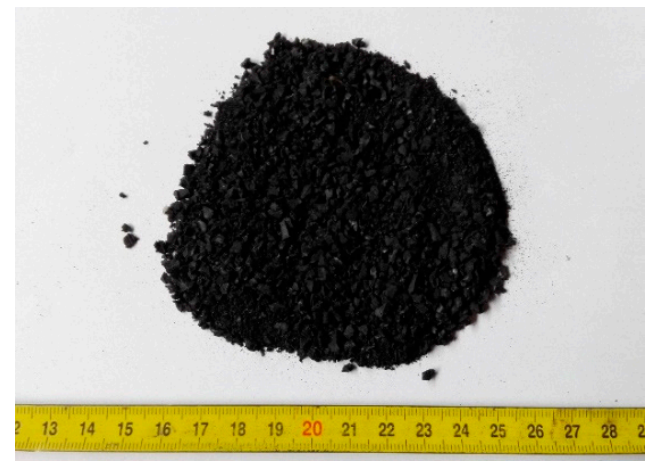

(a)

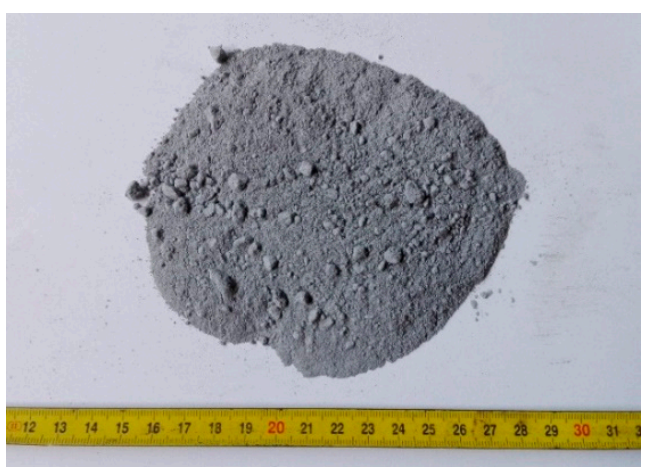

(b)

Figure 1. Test materials: (a) crumb rubber, (b) silica fume.

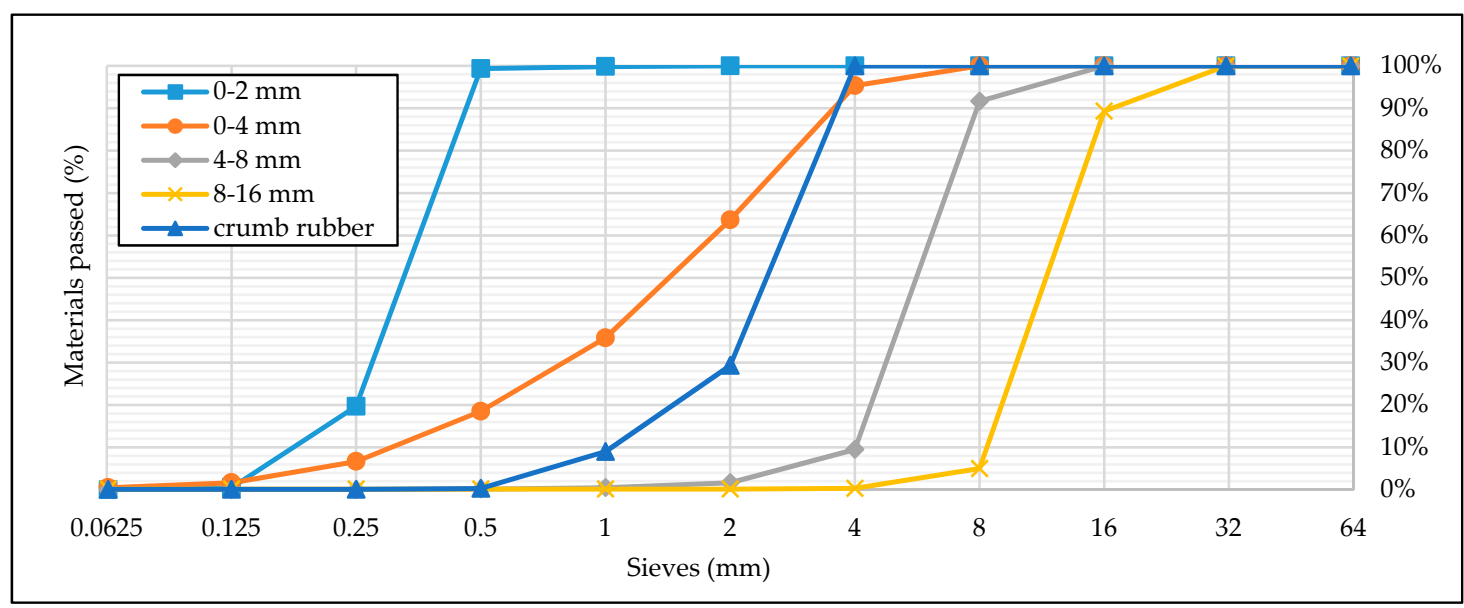

Figure 2. Sieve analysis of fine aggregate, coarse aggregate, and crumb rubber.

\subsection{Self-Compacting Concrete Mixtures Design}

A total of 21 self-compacting concrete mixtures were tested in fresh and hardened state, regarding two variables: crumb rubber and silica fume. Reference mixture with $0 \%$ of crumb rubber and $0 \%$ of silica fume was marked as SCC-0CR-0SLF. Three replacement levels of the cement with SLF $(0 \%, 5 \%$, and $10 \%$ by total cement mass) and seven replacement levels of the FA with CR $(0 \%, 5 \%, 10 \%, 15 \%$, $20 \%, 25 \%$, and $30 \%$ by total aggregate volume) were investigated. A summary of the SCC mixtures is listed in Table 4. SCC mixtures were designed having a constant water to binder $(\mathrm{w} / \mathrm{b})$ ratio of 0.4 and a total binder content of $450 \mathrm{~kg} / \mathrm{m}^{3}$. The water to powder ratio (w/p) was $1.07,1.05$, and 1.03 for SCC mixtures with $0 \%, 5 \%$, and $10 \%$ silica fume, respectively, and these values were in accordance with the permitted values given by European Guidelines for SCC [45]. For the reference SCC mixture, the percentage share of particular aggregate fractions of $0-2,0-4,4-8$ and $8-16 \mathrm{~mm}$ was $20 \%, 35 \%, 20 \%$, and $25 \%$ of total amount of aggregate volume, respectively. The dosage of SP was kept constant for all mixtures, while VMA was used only in concrete mixtures without silica fume, where slight segregation was observed. 
Table 4. Mix proportions for self-compacting concrete $\left(\mathrm{kg} / \mathrm{m}^{3}\right)$. CA: coarse aggregate, CR: crumb rubber, FA: fine aggregate, SLF: silica fume, w/b: water to binder.

\begin{tabular}{ccccccccccc}
\hline No & Mixture ID & Cement & SLF & Filler & FA & CA & CR & w/b & SP (\%) & VMA (\%) \\
\hline 1 & SCC-0CR-0SLF & 450 & 0 & 80 & 941.61 & 817.65 & 0 & 0.4 & 1.25 & 0.24 \\
2 & SCC-5CR-0SLF & 450 & 0 & 80 & 853.6 & 817.65 & 33.12 & 0.4 & 1.25 & 0.24 \\
3 & SCC-10CR-0SLF & 450 & 0 & 80 & 765.59 & 817.65 & 66.24 & 0.4 & 1.25 & 0.24 \\
4 & SCC-15CR-0SLF & 450 & 0 & 80 & 677.58 & 817.65 & 99.37 & 0.4 & 1.25 & 0.24 \\
5 & SCC-20CR-0SLF & 450 & 0 & 80 & 589.57 & 817.65 & 132.49 & 0.4 & 1.25 & 0.24 \\
6 & SCC-25CR-0SLF & 450 & 0 & 80 & 501.57 & 817.65 & 165.61 & 0.4 & 1.25 & 0.24 \\
7 & SCC-30CR-0SLF & 450 & 0 & 80 & 413.55 & 817.65 & 198.73 & 0.4 & 1.25 & 0.24 \\
8 & SCC-0CR-5SLF & 427.50 & 22.5 & 80 & 937.27 & 813.87 & 0 & 0.4 & 1.25 & - \\
9 & SCC-5CR-5SLF & 427.50 & 22.5 & 80 & 849.66 & 813.87 & 32.97 & 0.4 & 1.25 & - \\
10 & SCC-10CR-5SLF & 427.50 & 22.5 & 80 & 762.06 & 813.87 & 65.94 & 0.4 & 1.25 & - \\
11 & SCC-15CR-5SLF & 427.50 & 22.5 & 80 & 674.46 & 813.87 & 98.91 & 0.4 & 1.25 & - \\
12 & SCC-20CR-5SLF & 427.50 & 22.5 & 80 & 586.85 & 813.87 & 131.88 & 0.4 & 1.25 & - \\
13 & SCC-25CR-5SLF & 427.50 & 22.5 & 80 & 499.25 & 813.87 & 164.85 & 0.4 & 1.25 & - \\
14 & SCC-30CR-5SLF & 427.50 & 22.5 & 80 & 411.64 & 813.87 & 197.81 & 0.4 & 1.25 & - \\
15 & SCC-0CR-10SLF & 405 & 45 & 80 & 932.92 & 810.05 & 0 & 0.4 & 1.25 & - \\
16 & SCC-5CR-10SLF & 405 & 45 & 80 & 845.72 & 810.05 & 32.82 & 0.4 & 1.25 & - \\
17 & SCC-10CR-10SLF & 405 & 45 & 80 & 758.53 & 810.05 & 65.63 & 0.4 & 1.25 & - \\
18 & SCC-15CR-10SLF & 405 & 45 & 80 & 671.33 & 810.05 & 98.45 & 0.4 & 1.25 & - \\
19 & SCC-20CR-10SLF & 405 & 45 & 80 & 584.13 & 810.05 & 131.26 & 0.4 & 1.25 & - \\
20 & SCC-25CR-10SLF & 405 & 45 & 80 & 496.93 & 810.05 & 164.08 & 0.4 & 1.25 & - \\
21 & SCC-30CR-10SLF & 405 & 45 & 80 & 409.79 & 810.05 & 196.90 & 0.4 & 1.25 & - \\
\hline
\end{tabular}

\subsection{Specimen Preparation and Curing Conditions}

Designed SCC mixtures were stirred with a pan mixer that had a maximal capacity of $50 \mathrm{~L}$ (Figure 3). At the beginning, natural fine and coarse aggregate were mixed homogeneously for $120 \mathrm{~s}$, along with the water needed to have the natural aggregate saturated surface dry (SSD). The second step was to add silica fume, recycled crumb rubber, cement, filler, and about $75 \%$ of the total water volume, and the mixing was continued for another $2 \mathrm{~min}$. The third and final step was to add chemical admixtures, superplasticizer, and a viscosity-modifying admixture, along with the remaining $25 \%$ of total water volume, and the SCC was mixed for an additional $4 \mathrm{~min}$. Upon completion of the mixing process, fresh SCC properties were tested as described in Chapter 2.4. After testing the fresh SCC properties, concrete was cast into standardized molds, cylinders, and prisms, without any vibration or compaction, and protected with plastic foil for the next $24 \mathrm{~h}$. All test specimens were demolded $24 \mathrm{~h}$ after the casting and placed in a water tank for 4 weeks (Figure 4 ).

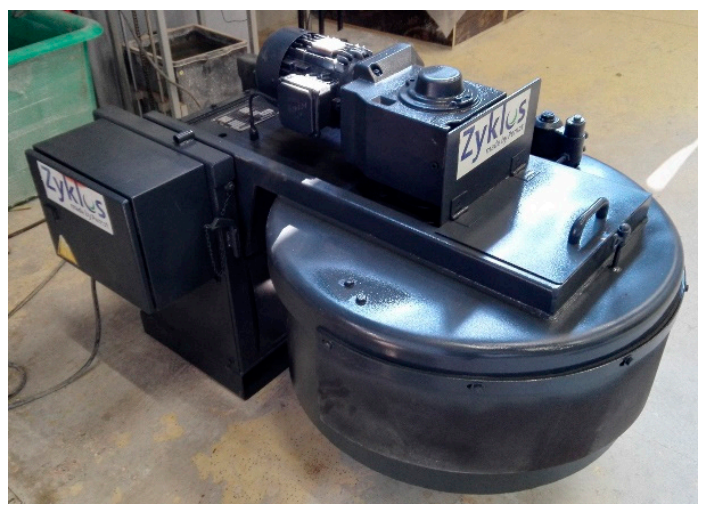

Figure 3. Pan mixer (50 L capacity). 


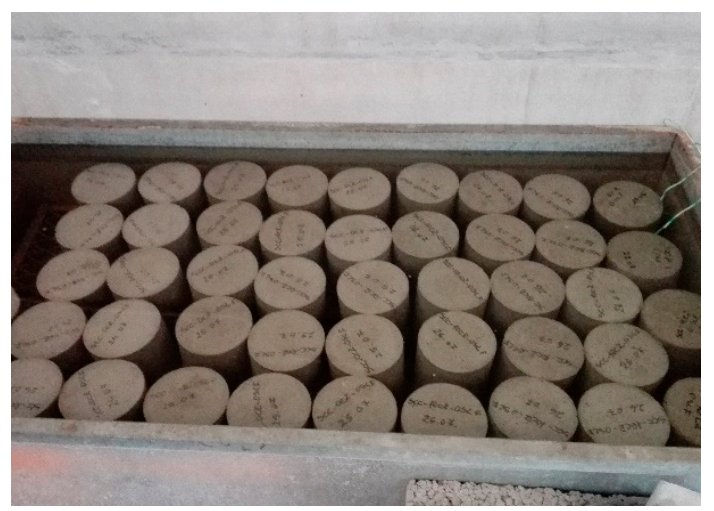

Figure 4. Pan mixer (50 L capacity).

The hardened state properties of SCC were determined after 28 days of water curing.

\subsection{Test Methods}

Tests on fresh and hardened SCC were performed according to relevant European standards. The J-ring test, L-box test, slump flow test, and segregation resistance test were performed according to EN 12350-12:2010 [53], EN 12350-10:2010 [54], EN 12350-8:2010 [55], and EN 12350-11:2010 [56], respectively. Flowability and viscosity of SCC were measured and classified through the slump flow test (Figure 5a). Passing ability was measured and classified through two different methods, the L-box and J-ring tests (Figure 5b), while segregation resistance was measured and classified through the sieve segregation test (Figure 5c).

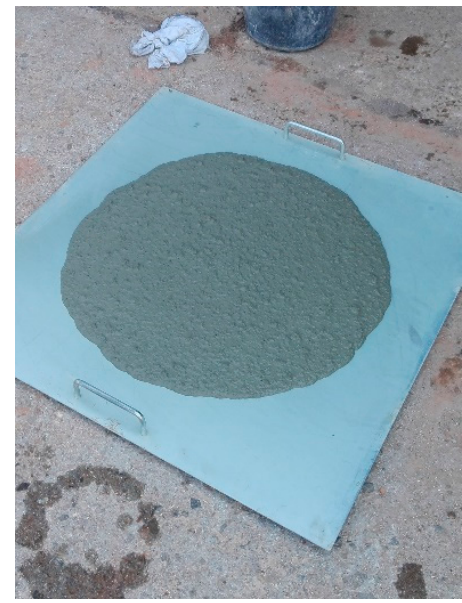

(a)

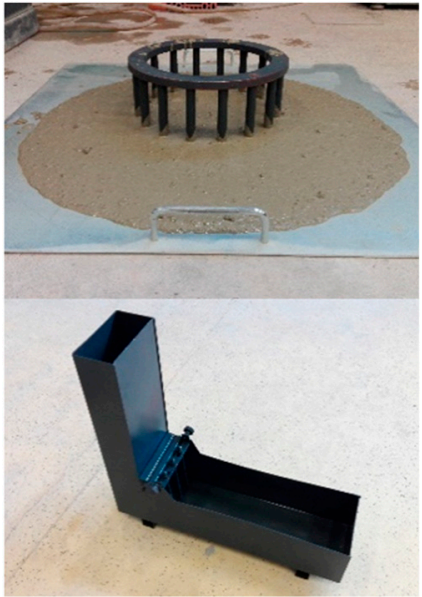

(b)

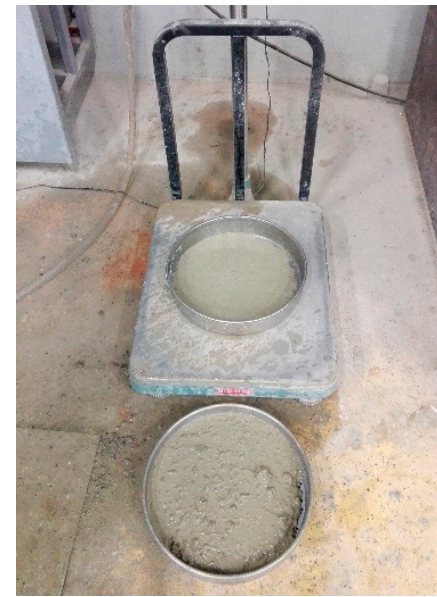

(c)

Figure 5. Test of fresh self-compacting concrete: (a) flowability and viscosity (slump flow test); (b) passing ability (J-ring and L-box); (c) segregation resistance (sieve segregation test).

Compressive strength $\left(\mathrm{f}_{\mathrm{ck}, \mathrm{cyl}}\right)$ was determined through testing cylinders (Figure 6a) with the dimensions of $\varnothing 150 \times 300 \mathrm{~mm}$ using EN 12390-3:2009 [57]. Flexural strength $\left(\mathrm{f}_{\mathrm{b}}\right)$ was tested on $100 \times 100 \times 400 \mathrm{~mm}$ prisms (Figure 6b) according to EN 12390-5:2009 [58]. The modulus of elasticity (E) was determined through testing cylinder specimens (Figure 6c) with the dimensions of $\varnothing 150 \times 300 \mathrm{~mm}$ using EN 12390-13:2013 [59]. 


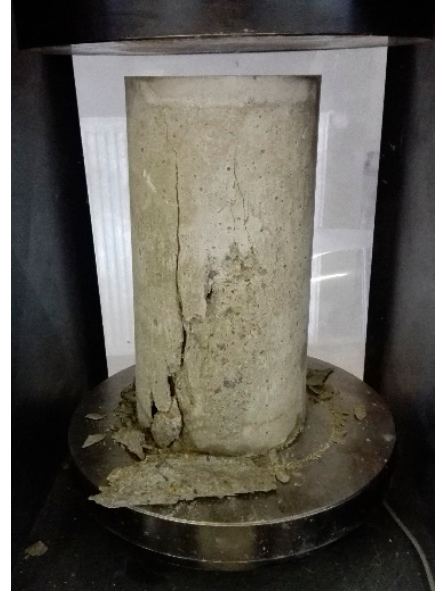

(a)

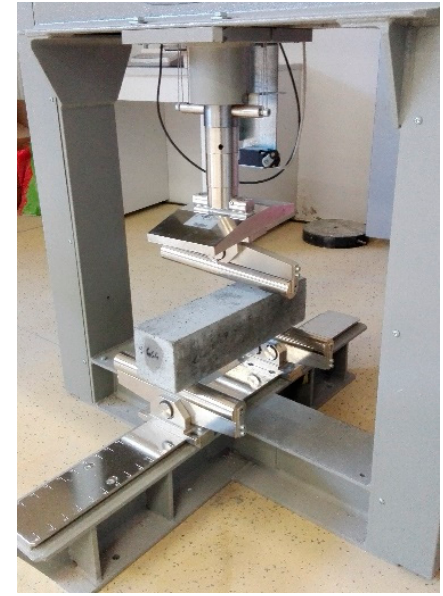

(b)

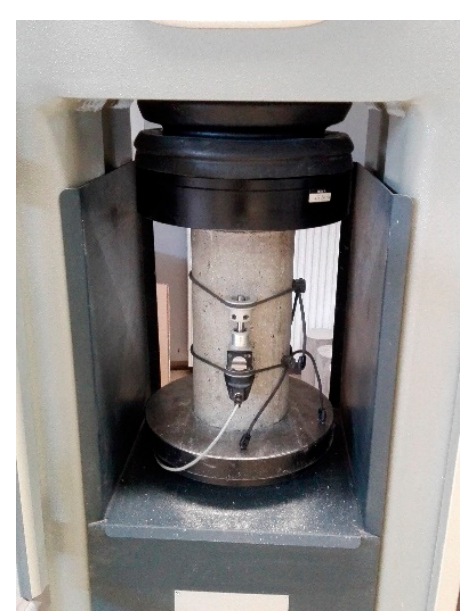

(c)

Figure 6. Test of hardened self-compacting concrete: (a) compressive strength; (b) flexural strength; (c) modulus of elasticity.

According to percentage values of the two main variables, i.e., silica fume and crumb rubber, a total of 126 cylinder specimens and 63 prism specimens were prepared. Three specimens were prepared for the same set of study parameters. The obtained results of compressive strength $\left(f_{c k}\right.$, cyl $)$, modulus of elasticity (E), and flexural strength $\left(f_{b}\right)$ were presented as the average of three samples. A summary of the tested properties of SCC in fresh and hardened states is given in Table 5.

Table 5. Tested self-compacting concrete (SCC) fresh and hardened state properties.

\begin{tabular}{ccc}
\hline State & SCC Property & Test and Specimen Type \\
\hline \multirow{3}{*}{ Fresh state } & Flowability $(\mathrm{d})$ & Slump flow test \\
& Viscosity (T500) & L-box test \\
& J-ring test \\
& Passing ability (PL and PJ) & Sieve segregation test \\
\hline \multirow{2}{*}{ Hardened state } & Compressive strength $\left(\mathrm{f}_{\mathrm{ck}, \mathrm{cyl}}\right)$ & Cylinder specimens dim. $\varnothing 150 \times 300 \mathrm{~mm}$ \\
& Modulus of elasticity $(\mathrm{E})$ & Prism specimens dim. $100 \times 100 \times 400 \mathrm{~mm}$ \\
\hline
\end{tabular}

\section{Results}

\subsection{Fresh SCC Properties}

The test results of the SCC properties in the fresh state are given in Table 6 and Figures 7-10. Segregation was not observed in all tested SCC mixtures; therefore, the sieve segregation test was conducted only when required after a visual assessment of the fresh concrete paste. 
Table 6. Test results of fresh SCC properties.

\begin{tabular}{|c|c|c|c|c|c|c|c|c|c|c|c|c|c|c|c|c|c|}
\hline \multicolumn{4}{|c|}{ SCC Fresh State Property } & \multirow{2}{*}{\multicolumn{3}{|c|}{$\begin{array}{c}\text { Viscosity } \\
\text { T500 }\end{array}$}} & \multirow{2}{*}{\multicolumn{3}{|c|}{$\begin{array}{l}\text { Flowability } \\
\text { Slump Flow }\end{array}$}} & \multicolumn{5}{|c|}{ Passing Ability } & \multirow{2}{*}{\multicolumn{3}{|c|}{$\begin{array}{c}\text { Segregation Resistance } \\
\text { Sieve Segregation }\end{array}$}} \\
\hline \multirow{3}{*}{$\begin{array}{c}\text { No } \\
1\end{array}$} & \multirow{3}{*}{$\begin{array}{c}\text { Mixture } \\
\text { SCC-0CR-0SLF }\end{array}$} & \multirow{3}{*}{$\begin{array}{c}\text { CR } \\
(\%) \\
0\end{array}$} & \multirow{3}{*}{$\begin{array}{c}\text { SLF } \\
(\%) \\
0\end{array}$} & & & & & & & $J-r i$ & & & -box & & & & \\
\hline & & & & \multirow{2}{*}{$\begin{array}{l}\text { (s) } \\
1.9\end{array}$} & \multicolumn{2}{|c|}{ Class } & \multirow{2}{*}{$\begin{array}{c}\mathrm{d}(\mathrm{mm}) \\
780\end{array}$} & \multicolumn{2}{|c|}{ Class } & \multirow{2}{*}{$\begin{array}{c}\text { PJ (mm) } \\
10\end{array}$} & \multirow{2}{*}{$\begin{array}{c}\text { Class } \\
10\end{array}$} & \multirow{2}{*}{$\begin{array}{c}\mathbf{P A}\left(\mathbf{H}_{\mathbf{2}} / \mathbf{H}_{\mathbf{1}}\right) \\
0.98\end{array}$} & \multicolumn{2}{|c|}{ Class } & \multirow{2}{*}{$\begin{array}{c}\text { SR (\%) } \\
11.83\end{array}$} & \multicolumn{2}{|c|}{ Class } \\
\hline & & & & & $<2$ & VS1 & & $760-850$ & SF3 & & & & $>0.80$ & PA2 & & $<15$ & SR2 \\
\hline 2 & SCC-5CR-0SLF & 5 & 0 & 1.9 & $<2$ & VS1 & 760 & $760-850$ & SF3 & 12.5 & $>10$ & 0.98 & $>0.80$ & PA2 & 10.1 & $<15$ & SR2 \\
\hline 3 & SCC-10CR-0SLF & 10 & 0 & 1.9 & $<2$ & VS1 & 750 & $660-750$ & SF2 & 13 & $>10$ & 0.96 & $>0.80$ & PA2 & 8.75 & $<15$ & SR2 \\
\hline 4 & SCC-15CR-0SLF & 15 & 0 & 2.3 & $>2$ & VS2 & 685 & $660-750$ & SF2 & 15 & $>10$ & 0.89 & $>0.80$ & PA2 & 8.33 & $<15$ & SR2 \\
\hline 5 & SCC-20CR-0SLF & 20 & 0 & 2.7 & $>2$ & VS2 & 690 & $660-750$ & SF2 & 25 & $>10$ & 0.89 & $>0.80$ & PA2 & 3.83 & $<15$ & SR2 \\
\hline 6 & SCC-25CR-0SLF & 25 & 0 & 3 & $>2$ & VS2 & 655 & $550-650$ & SF1 & 26 & $>10$ & 0.77 & $<0.80$ & PA2 & 3.43 & $<15$ & SR2 \\
\hline 7 & SCC-30CR-0SLF & 30 & 0 & 6.5 & $>2$ & VS2 & 555 & $550-650$ & SF1 & 41.25 & $>10$ & 0.42 & $<0.80$ & PA2 & 2.58 & $<15$ & SR2 \\
\hline 8 & SCC-0CR-5SLF & 0 & 5 & 1.7 & $<2$ & VS1 & 750 & $660-750$ & SF2 & 10 & 0 & 0.97 & $>0.80$ & PA2 & - & $<15$ & SR2 \\
\hline 9 & SCC-5CR-5SLF & 5 & 5 & 1.9 & $<2$ & VS1 & 690 & $660-750$ & SF2 & 16.25 & $>10$ & 0.95 & $>0.80$ & PA2 & - & $<15$ & SR2 \\
\hline 10 & SCC-10CR-5SLF & 10 & 5 & 1.9 & $<2$ & VS1 & 682 & $660-750$ & SF2 & 17.25 & $>10$ & 0.93 & $>0.80$ & PA2 & - & $<15$ & SR2 \\
\hline 11 & SCC-15CR-5SLF & 15 & 5 & 1.9 & $<2$ & VS1 & 644 & $550-650$ & SF1 & 20 & $>10$ & 0.9 & $>0.80$ & PA2 & - & $<15$ & SR2 \\
\hline 12 & SCC-20CR-5SLF & 20 & 5 & 2.5 & $>2$ & VS2 & 600 & $550-650$ & SF1 & 28.25 & $>10$ & 0.68 & $<0.80$ & PA2 & - & $<15$ & SR2 \\
\hline 13 & SCC-25CR-5SLF & 25 & 5 & 3.2 & $>2$ & VS2 & 555 & $550-650$ & SF1 & 29.75 & $>10$ & 0.64 & $<0.80$ & PA2 & - & $<15$ & SR2 \\
\hline 14 & SCC-30CR-5SLF & 30 & 5 & 8.6 & $>2$ & VS2 & 495 & - & - & 34 & $>10$ & 0.38 & $<0.80$ & PA2 & - & $<15$ & SR2 \\
\hline 15 & SCC-0CR-10SLF & 0 & 10 & 1.5 & $<2$ & VS1 & 690 & $660-750$ & SF2 & 6.25 & $<10$ & 0.87 & $>0.80$ & PA2 & - & $<15$ & SR2 \\
\hline 16 & SCC-5CR-10SLF & 5 & 10 & 1.6 & $<2$ & VS1 & 685 & $660-750$ & SF2 & 9.5 & $<10$ & 0.86 & $>0.80$ & PA2 & - & $<15$ & SR2 \\
\hline 17 & SCC-10CR-10SLF & 10 & 10 & 1.7 & $<2$ & VS1 & 670 & $660-750$ & SF2 & 9.75 & $<10$ & 0.81 & $>0.80$ & PA2 & - & $<15$ & SR2 \\
\hline 18 & SCC-15CR-10SLF & 15 & 10 & 1.8 & $<2$ & VS1 & 670 & $660-750$ & SF2 & 11 & $>10$ & 0.74 & $<0.80$ & PA2 & - & $<15$ & SR2 \\
\hline 19 & SCC-20CR-10SLF & 20 & 10 & 1.9 & $<2$ & VS1 & 685 & $660-750$ & SF2 & 12 & $>10$ & 0.78 & $<0.80$ & PA2 & - & $<15$ & SR2 \\
\hline 20 & SCC-25CR-10SLF & 25 & 10 & 2.1 & $>2$ & VS2 & 655 & $550-650$ & SF1 & 13.75 & $>10$ & 0.78 & $<0.80$ & PA2 & - & $<15$ & SR2 \\
\hline 21 & SCC-30CR-10SLF & 30 & 10 & 4.4 & $>2$ & VS2 & 505 & - & - & 30.5 & $>10$ & 0.35 & $>0.80$ & PA2 & - & $<15$ & SR2 \\
\hline
\end{tabular}




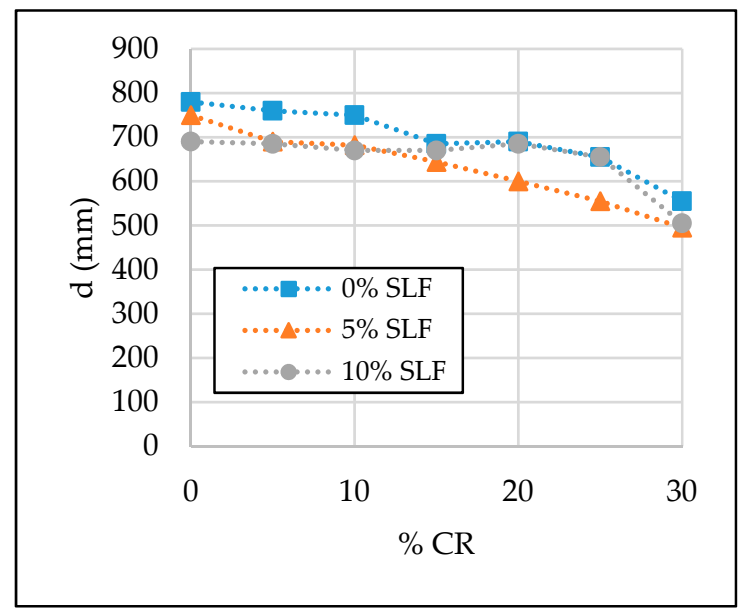

Figure 7. The effect of crumb rubber and silica fume on slump flow diameter.

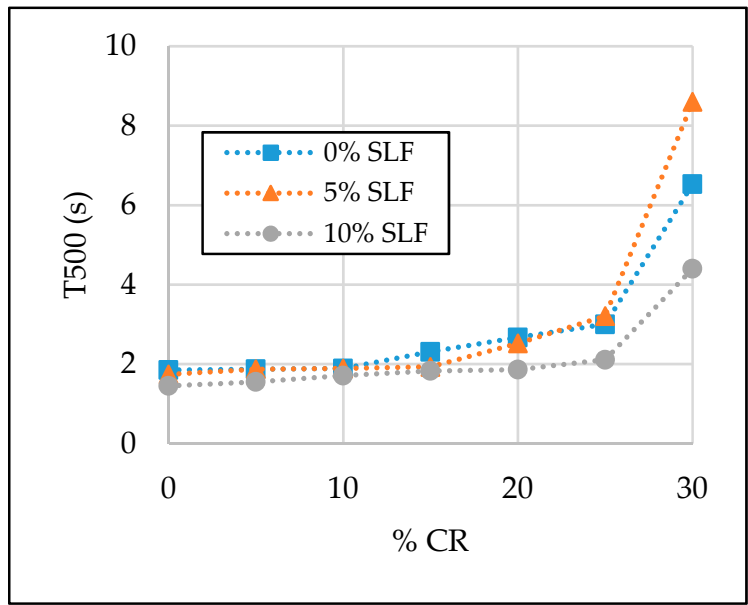

Figure 8. The effect of crumb rubber and silica fume on T500 time.

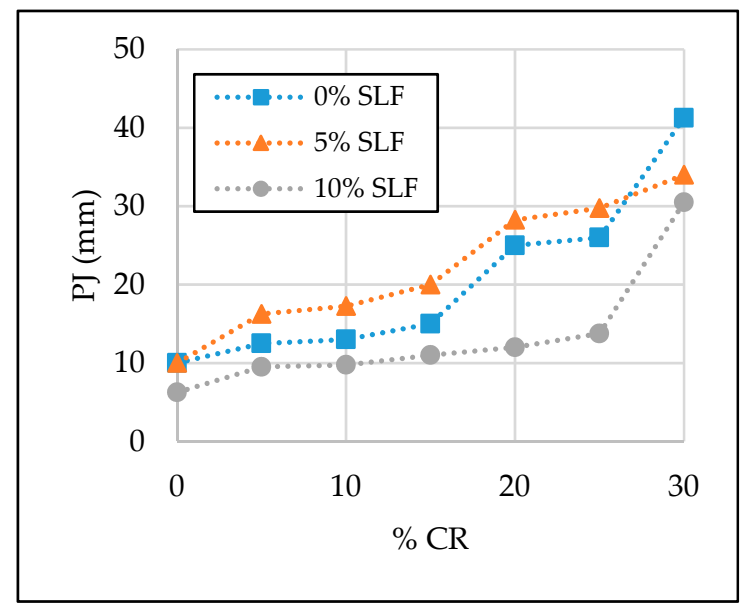

Figure 9. The effect of crumb rubber and silica fume on J-ring value (PJ). 


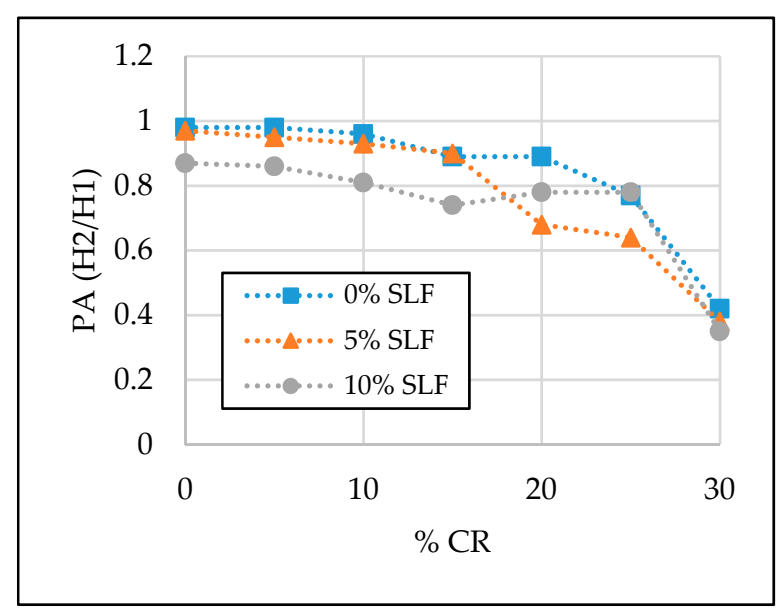

Figure 10. The effect of crumb rubber and silica fume on L-box values $\left(\mathrm{PA}=\mathrm{H}_{2} / \mathrm{H}_{1}\right)$.

\subsubsection{Flowability}

From Table 6 and Figure 7, it can be seen that the inclusion of CR and SLF in SCC caused the reduction of its flowability. Among the 21 observed SCC mixtures, reference mixture SCC-0CR-0SLF has the highest value of the slump flow diameter, i.e., $780 \mathrm{~mm}$, while minimum values of the slump flow diameter occur with mixtures SCC-30CR-5SLF and SCC-30CR-10SLF, which were 495 and $505 \mathrm{~mm}$, respectively. Slump flow class (SF) was also changed according to the crumb rubber and silica fume amount in SCC. With a higher replacement level of fine aggregate, slump flow values change from class SF3 to classes SF2 and SF1, which can be considered as a negative effect of these two replacement materials on concrete flowability. Similarly, with a higher replacement level of cement with silica fume, values of the slump flow diameter take the value of flowability class SF1 and SF2. However, it can be concluded that the results of slump flow diameter are satisfied and in accordance with EFNARC guidelines, except for those of concrete mixtures SCC-30CR-5SLF and SCC-30CR-10SLF, where the values of slump flow diameter were below $550 \mathrm{~mm}$, which was most likely because of the crumb rubber rough surface, surface friction, and sharp edges of the rubber particles [2,5] causing blockages.

\subsubsection{Viscosity}

T500 (s) was used as a viscosity indicator of SCC mixtures. From Table 6 and Figure 8, it can be seen that the CR and SLF inclusion caused the enhancement in viscosity of the SCC mixtures. On the opposite hand, with the inclusion of silica fume, the T500 value was less affected. With $0 \%$ of crumb rubber, the T500 value was $1.85,1.74$ and $1.45 \mathrm{~s}$ with $0 \%, 5 \%$, and $10 \%$ of silica fume, respectively. Both viscosity classes (VS1 and VS2) are connected with the test results of the T500 parameter; hence, the majority of the SCC mixtures with up to $15 \%$ of crumb rubber and up to $10 \%$ of silica fume can be classified as viscosity class VS1 because T500 value was below $2 \mathrm{~s}$, which is exceptionally suitable for reinforced structural elements with congested reinforcement. The greatest value of T500 test results was with the $30 \%$ fine aggregate replacement and $10 \%$ cement replacement. From the given results, it can be suggested than test results with up to $20 \%$ of crumb rubber and up to $10 \%$ of silica fume are reasonable and acceptable.

\subsubsection{L-box and J-ring}

The passing ability of fresh concrete mixture can be of great significance during the execution of concrete works at a construction site, if reinforcement is congested. Therefore, before casting concrete into molds, their passing ability was checked with two different test methods: L-box and J-ring. From test results given in Table 6 and Figures 9 and 10, it can be concluded that by increasing the replacement level of natural fine aggregate and cement with crumb rubber and silica fume, the passing ability of SCC mixtures was reduced. Most of the obtained J-ring test results are between 10 and $15 \mathrm{~mm}$, and the 
upper limit according to EFNARC guidelines for SCC is $10 \mathrm{~mm}$. This can be improved with a slight increase in the superplasticizer dosage. On the other hand, the test results obtained with L-box show a satisfactory passing ability of SCC mixture with up to a 15\% replacement level of natural fine aggregate with crumb rubber and with up to a $10 \%$ replacement level of cement with silica fume. Values of passing ability (PA) were higher than the limit value for the mentioned mixtures, i.e., $>0.8$. However, the PA value decreased drastically when $30 \%$ of natural fine aggregate was replaced with crumb rubber. The PA was $0.42,0.38$, and 0.35 for mixtures with $30 \%$ crumb rubber and $0 \%, 5 \%$, and $10 \%$ silica fume, respectively.

\subsubsection{Segregation Resistance}

The appearance of segregation can be pronounced in high vertical-reinforced concrete elements such as columns, pylons, etc. The sieve segregation resistance test, which is defined as a percentage of concrete passed through a $5 \mathrm{~mm}$ sieve, can be of great help to bring conclusions regarding concrete homogeneity and concrete strength uniformity. According to the test results given in Table 6, it is clear that segregation resistance was not measured for all the concrete mixtures, since segregation was not present in all the SCC mixtures. After completion of the slump-flow, J-ring, and L-box test for each mixture, a visual inspection was made regarding whether there is water separation at the edge of the concrete or not. If there was any, the sieve segregation resistance test was made. A slight segregation was present almost in all mixtures without silica fume. Hence, viscosity-modifying admixture was added to increase segregation resistance and cohesion, in the amount of $0.24 \%$ cement mass, in order to achieve the desired segregation resistance class SR2, i.e., below 15\%. According to the test results given in Table 6, it can be concluded that all SCC mixtures without silica fume have segregation resistance value (SR) within the permissible limits given by the EFNARC Guidelines. SCRC mixtures containing silica fume as a supplementary cementitious material did not have pronounced water separation at the edge of the concrete; therefore, the sieve segregation resistance test was not performed.

The test results of the SCC fresh state properties were in accordance with investigations carried out by different authors so far $[8,44,60,61]$, where fine aggregate $(0-4 \mathrm{~mm})$ was replaced with crumb rubber. This behavior can be explained by the sharp edges [2,5] of rubber particles causing blockages; hence, more energy is required to move concrete paste and an enhancement in viscosity and reduction in flowability and passing ability occurs. However, with up to $15 \%$ of the fine aggregate replacement level and 5\% of the cement replacement level, favorable fresh SCC properties classes can be obtained.

\subsection{Hardened SCC Properties}

The test results of the SCC properties in the hardened state are given in Table 7 and Figures 11-14.

Table 7. Test results of hardened SCC properties.

\begin{tabular}{|c|c|c|c|c|c|c|c|c|c|c|c|}
\hline \multirow{2}{*}{ R.b. } & \multirow{2}{*}{ Mixture } & \multirow{2}{*}{$\begin{array}{c}\text { Dry Unit Weight }\left(\mathrm{kg} / \mathrm{m}^{3}\right) \\
\text { Mean }\end{array}$} & \multicolumn{3}{|c|}{$\mathrm{f}_{\mathrm{ck}, \mathrm{cyl}}(\mathrm{MPa})$} & \multicolumn{3}{|c|}{ E (GPa) } & \multicolumn{3}{|c|}{$\mathrm{f}_{\mathrm{b}}(\mathrm{MPa})$} \\
\hline & & & Mean & st dev. & $\mathrm{CV} \%$ & Mean & st dev. & $\mathrm{CV} \%$ & Mean & st dev. & $\mathrm{CV} \%$ \\
\hline 1 & SCC-0CR-0SLF & 2424.89 & 43.72 & 2.54 & $5.82 \%$ & 38.58 & 2.95 & $5.82 \%$ & 6.30 & 0.14 & $2.23 \%$ \\
\hline 2 & SCC-5CR-0SLF & 2378.23 & 39.04 & 3.10 & $7.93 \%$ & 34.89 & 2.27 & $6.50 \%$ & 6.17 & 0.22 & $3.55 \%$ \\
\hline 3 & SCC-10CR-0SLF & 2329.60 & 30.88 & 1.82 & $5.89 \%$ & 32.92 & 4.70 & $14.26 \%$ & 5.15 & 0.10 & $2.01 \%$ \\
\hline 4 & SCC-15CR-0SLF & 2305.52 & 28.04 & 1.41 & $5.04 \%$ & 28.30 & 1.28 & $4.52 \%$ & 5.21 & 0.18 & $3.37 \%$ \\
\hline 5 & SCC-20CR-0SLF & 2212.76 & 22.76 & 1.29 & $5.67 \%$ & 22.30 & 2.04 & $9.15 \%$ & 3.95 & 0.08 & $1.96 \%$ \\
\hline 6 & SCC-25CR-0SLF & 2151.96 & 13.28 & 1.98 & $14.93 \%$ & 16.50 & 2.03 & $12.30 \%$ & 3.69 & 0.43 & $11.58 \%$ \\
\hline 7 & SCC-30CR-0SLF & 2070.74 & 12.71 & 0.52 & $4.05 \%$ & 14.99 & 1.30 & $8.66 \%$ & 1.85 & 0.27 & $14.56 \%$ \\
\hline 8 & SCC-0CR-5SLF & 2391.46 & 46.48 & 5.05 & $10.87 \%$ & 37.37 & 4.03 & $10.79 \%$ & 6.63 & 0.25 & $3.79 \%$ \\
\hline 9 & SCC-5CR-5SLF & 2318.86 & 43.98 & 3.11 & $7.07 \%$ & 36.20 & 3.25 & $8.97 \%$ & 6.24 & 0.02 & $0.32 \%$ \\
\hline 10 & SCC-10CR-5SLF & 2302.14 & 37.42 & 1.30 & $3.48 \%$ & 31.97 & 0.60 & $1.88 \%$ & 5.47 & 0.16 & $2.85 \%$ \\
\hline 11 & SCC-15CR-5SLF & 2250.54 & 30.89 & 2.08 & $6.72 \%$ & 28.06 & 3.37 & $12.01 \%$ & 5.32 & 0.24 & $4.53 \%$ \\
\hline 12 & SCC-20CR-5SLF & 2189.49 & 23.08 & 1.76 & $7.65 \%$ & 24.71 & 0.06 & $0.24 \%$ & 4.69 & 0.07 & $1.44 \%$ \\
\hline 13 & SCC-25CR-5SLF & 2105.02 & 18.26 & 0.10 & $0.55 \%$ & 18.54 & 4.15 & $22.38 \%$ & 4.48 & 0.09 & $1.99 \%$ \\
\hline 14 & SCC-30CR-5SLF & 2057.35 & 15.35 & 0.95 & $6.20 \%$ & 15.75 & 1.43 & $6.20 \%$ & 3.87 & 0.06 & $1.44 \%$ \\
\hline 15 & SCC-0CR-10SLF & 2411.98 & 66.30 & 1.39 & $2.09 \%$ & 49.26 & 1.10 & $2.23 \%$ & 7.38 & 0.23 & $3.07 \%$ \\
\hline 16 & SCC-5CR-10SLF & 2331.30 & 60.83 & 5.23 & $8.60 \%$ & 48.06 & 4.18 & $8.69 \%$ & 6.58 & 0.28 & $4.31 \%$ \\
\hline 17 & SCC-10CR-10SLF & 2311.11 & 42.73 & 4.48 & $10.48 \%$ & 41.94 & 2.70 & $6.44 \%$ & 6.27 & 0.17 & $2.75 \%$ \\
\hline
\end{tabular}


Table 7. Cont.

\begin{tabular}{|c|c|c|c|c|c|c|c|c|c|c|c|}
\hline \multirow{2}{*}{ R.b. } & \multirow{2}{*}{ Mixture } & \multirow{2}{*}{$\begin{array}{c}\text { Dry Unit Weight }\left(\mathrm{kg} / \mathrm{m}^{3}\right) \\
\text { Mean }\end{array}$} & \multicolumn{3}{|c|}{$\mathrm{f}_{\mathrm{ck}, \mathrm{cyl}}(\mathrm{MPa})$} & \multicolumn{3}{|c|}{ E (GPa) } & \multicolumn{3}{|c|}{$\mathrm{f}_{\mathrm{b}}(\mathrm{MPa})$} \\
\hline & & & Mean & st dev. & $\mathrm{CV} \%$ & Mean & st dev. & $\mathrm{CV} \%$ & Mean & st dev. & CV \% \\
\hline 18 & SCC-15CR-10SLF & 2266.57 & 33.11 & 3.22 & $9.72 \%$ & 37.69 & 2.78 & $7.39 \%$ & 5.88 & 0.26 & $4.35 \%$ \\
\hline 19 & SCC-20CR-10SLF & 2194.11 & 25.04 & 1.85 & $7.38 \%$ & 36.28 & 4.62 & $12.75 \%$ & 5.07 & 0.03 & $0.58 \%$ \\
\hline 20 & SCC-25CR-10SLF & 2108.65 & 24.28 & 2.47 & $10.16 \%$ & 26.42 & 3.40 & $12.87 \%$ & 4.87 & 0.19 & $4.00 \%$ \\
\hline 21 & SCC-30CR-10SLF & 2069.84 & 18.96 & 4.29 & $22.64 \%$ & 23.68 & 1.10 & $4.64 \%$ & 4.46 & 0.19 & $4.35 \%$ \\
\hline
\end{tabular}

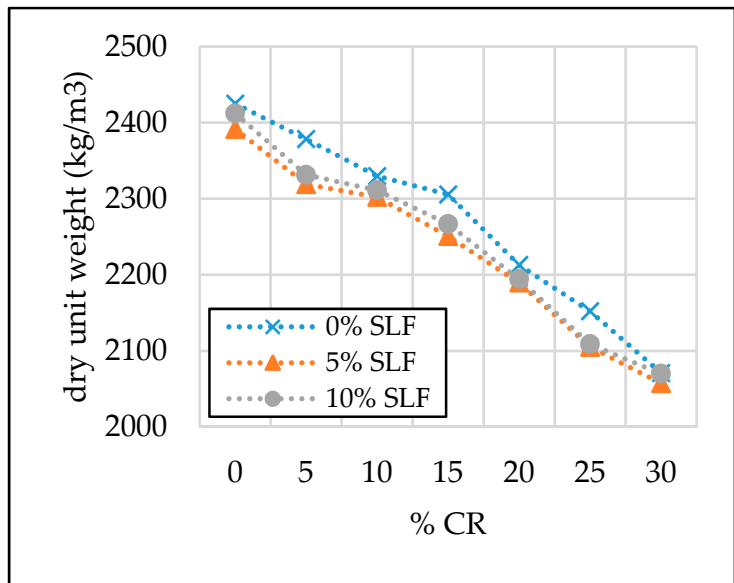

Figure 11. The effect of crumb rubber and silica fume on dry unit weight.

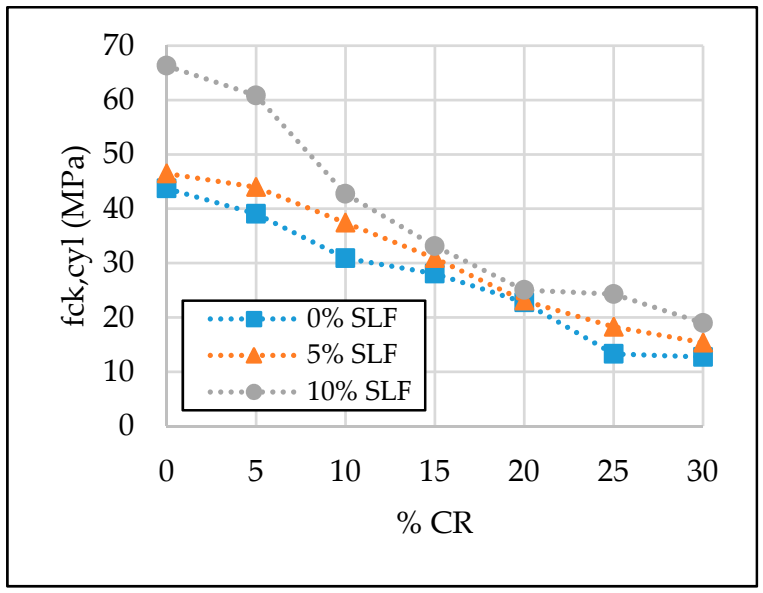

Figure 12. The effect of crumb rubber and silica fume on 28-day compressive strength.

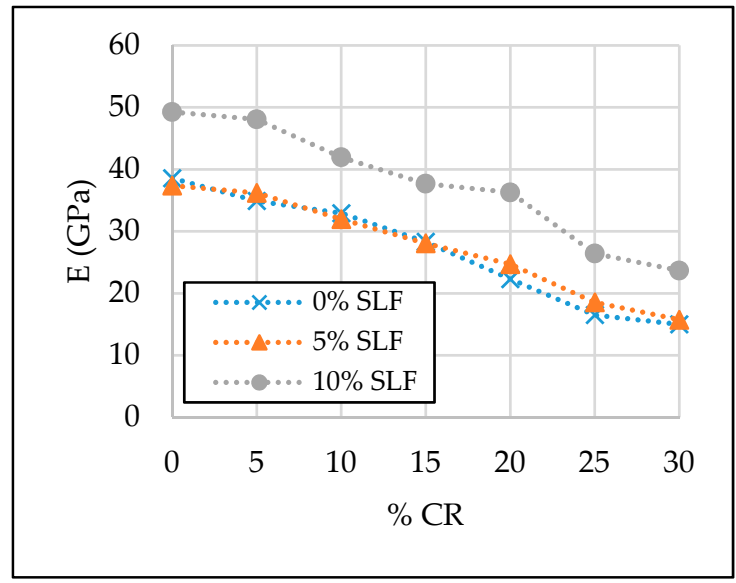

Figure 13. The effect of crumb rubber and silica fume on 28-day modulus of elasticity. 


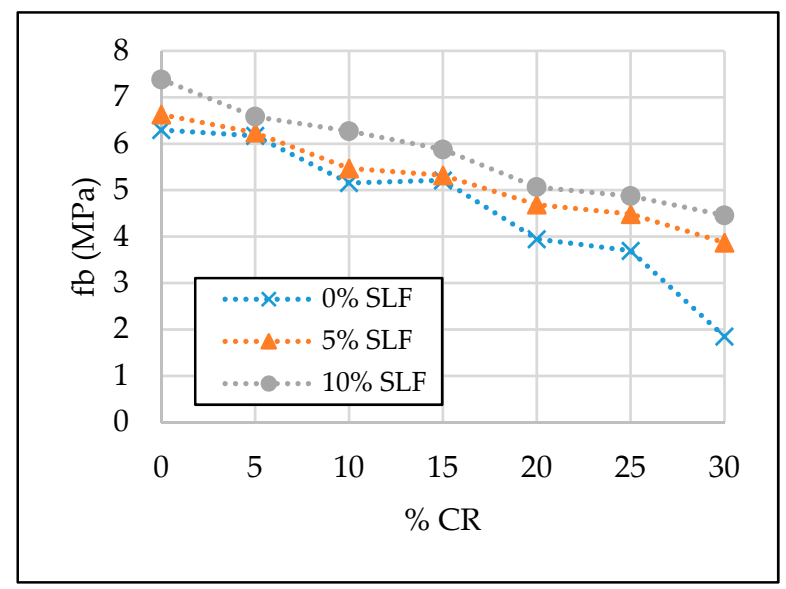

Figure 14. The effect of crumb rubber and silica fume on 28-day flexural strength.

\subsubsection{Dry Unit Weight}

The unit weight of SCC cylinders and prisms was measured after 28 days. The results given in Table 7 and Figure 11 show that the dry unit weight decreases with an increasing content of crumb rubber due to its low specific gravity $\left(1.05 \mathrm{~g} / \mathrm{cm}^{3}\right)$. The relative decrease in dry unit weight was approximately $7 \%$ and $15 \%$ with $15 \%$ and $30 \%$ replacement levels of fine aggregate and $0 \%$ and $5 \%$ replacement levels of cement, respectively. An almost linear relationship between a reduction in dry unit weight and increase of replacement level of natural fine aggregate with crumb rubber was observed. Lightweight self-compacting concrete with a dry unit weight around $2069 \mathrm{~kg} / \mathrm{m}^{3}$ was obtained, with $30 \%$ of the fine aggregate replacement level, which ultimately leads to a lower total mass of the concrete structures if such concrete is intended for structural purposes.

\subsubsection{Compressive Strength $\left(f_{c k, c y l}\right)$}

As expected, the mean value of three measurements of 28-day compressive strength was the lowest, i.e., $12.21 \mathrm{MPa}$, when the CR and SLF replacement levels were $30 \%$ and $0 \%$, respectively. The negative impact of CR on the 28-day compressive strength can be described with a poor rubber granule-cement paste bond and with a low rubber modulus of elasticity compared to natural aggregates $[5,62]$. On the contrary, the mean value of three measurements of 28-day compressive strength was the greatest when the replacement level of cement with silica fume was $10 \%$, with $0 \%$ of crumb rubber content, i.e., $66.30 \mathrm{MPa}$ (Table 7, Figure 12). As a result of its pozzolanic activity, silica fume contributes to the increase in values of not only its compressive strength, but also the modulus of elasticity and flexural strength. However, according to the obtained results and due to the economic criteria, it can be suggested that silica fume should be used in combination with recycled rubber only up to a $5 \%$ replacement level of the cement. Any replacement above $5 \%$ is questionable in terms of cost-effectiveness, because of the relatively big drop in the compressive strength of SCRC cylinder specimens at higher replacement levels of fine aggregate with recycled crumb rubber. Compared to reference mixture SCC-OCR-0SLF, the value of the 28 -day compressive strength of the mixture SCC-30CR-0SLF was reduced by $71 \%$. This reduction is alleviated in case of $30 \%$ crumb rubber and $5 \%$ or $10 \%$ silica fume, but it is still significant, at $65 \%$ and $57 \%$, respectively. Consequently, it can be seen that at a higher replacement level of fine aggregate with crumb rubber, i.e., $30 \%$, silica fume as a supplementary cementitious material can reduce the negative effect by up to $14 \%$. In other words, the positive effect of adding silica fume to self-compacting rubberized concrete is more noticeable on a lower fine aggregate replacement level, i.e., up to $10 \%$. With $5 \%$ silica fume and $5 \%$ crumb rubber, the values of the 28 -day compressive strength are almost equal to the compressive strength value of the reference SCC mixture. A similar occurrence is with $10 \%$ silica fume, where the improvement is even higher. In this case, the value of the 28 -day compressive strength is $39 \%$ higher than the value of the reference SCC mixture. Only three 
values of the 28-day compressive strength were below the limit value for structural applications of $17 \mathrm{MPa}$ [9], i.e., SCC-25CR-0SLF, SCC-30CR-0SLF, and SCC-30CR-5SLF. On the other hand, values of the 28-day compressive strength of the SCC mixtures labeled as SCC-15CR-5SLF and SCC-10CR-0SLF were above $30 \mathrm{MPa}$, which sound promising for the future investigation of self-compacting concrete on the structural elements and systems.

\subsubsection{Modulus of Elasticity (E)}

Values of the 28-day modulus of elasticity were in a direct link with the compressive strength values, although in this case, the negative effect of replacing natural fine aggregate with crumb rubber is more pronounced, since with $5 \%$ of silica fume, the negative impact of rubber granules on the elasticity modulus values cannot be annulled (Table 7, Figure 13). Compared to the value of the modulus of elasticity of reference mixture SCC-0CR-0SLF, a reduction of approximately $56 \%$ can be observed with $30 \%$ of crumb rubber. The beneficial effect of replacing cement with silica fume was manifested at concrete mixtures with $0 \%, 5 \%$, and $10 \%$ of crumb rubber and $10 \%$ of silica fume, where supplementary cementitious material contributed to a relative increase in the values of the modulus of elasticity by $28 \%, 25 \%$ and $9 \%$, respectively. However, with $15 \%$ of crumb rubber and $0 \%, 5 \%$, and $10 \%$ of silica fume, the reduction in modulus of elasticity was $27 \%, 27 \%$, and $2 \%$. An explanation for these values of modulus of elasticity of the SCC with crumb rubber and silica fume can be described in the same way as with the compressive strength values. However, the negligible positive impact of the $5 \%$ replacement level of cement with silica fume on the values of the modulus of elasticity can be reported. Nevertheless, up to a $20 \%$ fine aggregate replacement level, values of the 28-day modulus of elasticity were over $20 \mathrm{GPa}$.

\subsubsection{Flexural Strength $\left(\mathrm{f}_{\mathrm{b}}\right)$}

Flexural strength also experienced a negative impact with replacing natural fine aggregate with crumb rubber, but this was still at smaller percentage compared to the compressive strength and modulus of elasticity (Table 7, Figure 14). Thus, it can be noted that compared to the reference mixture, a maximum reduction in the value of the 28-day flexural strength was $71 \%$ for the mixture SCC-30CR-0SLF. However, this reduction is significantly less, i.e., 39\% and 29\%, when 5\% and 10\% of cement was replaced with silica fume, for an equal crumb rubber replacement level of $30 \%$. Despite the relative reduction in the flexural strength of the SCC mixture SCC-30CR-0SLF being equal to the relative reduction in compressive strength for the same mixture, i.e., $71 \%$, other percentages of relative reduction of the flexural strength were still much lower compared to other percentages of relative reduction of the compressive strength. For example, the relative reduction in 28-day flexural strength for SCC-15CR-5SLF was only $16 \%$, compared to a $29 \%$ relative reduction in the 28 -day compressive strength for the same mixture. Similar behavior was also reported by several different authors $[7,11,32,45]$ who also used crumb rubber as a fine aggregate replacement.

\subsection{Prediction Models for SCC Mechanical Properties}

The experimental dataset for the present work is based on 63 values of the observed mechanical properties: three for each of 21 SCC mixtures (an experimental dataset can be provided on request). To predict the three main mechanical properties of SCC — compressive strength, modulus of elasticity and flexural strength-a multivariate regression technique was applied for each of the observed mechanical properties by using two independent variables: the amount of crumb rubber (0-30\%) and silica fume (0-10\%). Regression models were extracted by using software "Statistica 13" and " $R$ ". The final models are given in Table 8. 
Table 8. Final regression models for the prediction of the mechanical properties with corresponding estimated regression equations.

\begin{tabular}{cc}
\hline Mechanical Property & Final Regression Model \\
\hline Compressive strength $\left(\mathrm{f}_{\mathrm{ck}}\right)$ & $\mathrm{b} 0+\mathrm{b} 1 \times \mathrm{cr}+\mathrm{b} 2 \times \mathrm{slf}+\mathrm{b} 3 \times \mathrm{cr} \times \mathrm{slf}+\varepsilon$ \\
Flexural strength $\left(\mathrm{f}_{\mathrm{b}}\right)$ & $\mathrm{b} 0+\mathrm{b} 1 \times \mathrm{cr}+\mathrm{b} 2 \times \mathrm{slf}+\mathrm{b} 3 \times \mathrm{cr} \times \mathrm{slf}+\varepsilon$ \\
Modulus of elasticity $(\mathrm{E})$ & $\mathrm{b} 0+\mathrm{b} 1 \times \mathrm{cr}+\mathrm{b} 2 \times \exp (\mathrm{slf})+\varepsilon$ \\
\hline
\end{tabular}

b0, b1, b2, b3-regression coefficients. $\varepsilon$-model error. cr-replacement level of natural fine aggregate with crumb rubber $(\%)$. slf-replacement level of cement with silica fume $(\%)$.

Multivariate regression models have been developed for the partial replacement of natural fine aggregate with crumb rubber $(0-30 \%)$ and the partial replacement of cement with silica fume $(0-10 \%)$. For the estimation of unknown parameters of modulus of elasticity, the least squares (LS) method was used. However, when applying the LS method for the estimation of unknown parameters of the other two mechanical properties, i.e., compressive strength and flexural strength, the variability of the variance of the residuals was observed, depending on the silica fume replacement level. Hence, for an estimation of unknown parameters of compressive strength and flexural strength, the weighted least squares (WLS) method was used. In these cases, weights for WLS were determined by modeling squares of residuals in the initial model with the silica fume replacement level. The results of the regression analysis and estimated coefficients for all three mechanical properties are given in Tables 9-11.

Table 9. Results of the regression analysis and coefficient estimation-compressive strength $($ fck $=43.09240-1.07104 \times \mathrm{cr}+1.72105 \times$ slf $-0.04515 \times \mathrm{cr} \times$ slf $)$.

\begin{tabular}{ccccccc}
\hline Coefficient & Estimate & Std. Error & $\operatorname{Pr}(>|\mathbf{t}|)$ & $\mathbf{2 . 5 \%}$ & $\mathbf{9 7 . 5 \%}$ & Adj. $\mathbf{R}^{\mathbf{2}}$ \\
\hline b0 & 43.09240 & 0.81541 & $<2 \mathrm{e}^{-16}$ & 41.46076 & 44.72403 & \\
b1 & -1.07104 & 0.04523 & $<2 \mathrm{e}^{-16}$ & -1.16154 & -0.98053 & 0.9391 \\
b2 & 1.72105 & 0.21431 & $4.86 \mathrm{e}^{-11}$ & 1.29221 & 2.14988 & \\
b3 & -0.04515 & 0.01189 & 0.00034 & -0.06893 & -0.02136 & \\
\hline
\end{tabular}

Table 10. Results of the regression analysis and coefficient estimation—modulus of elasticity $(E=39.7295$ $-0.836401 \times \mathrm{cr}+0.000473885 \times \exp (\mathrm{slf})$.

\begin{tabular}{ccccccc}
\hline Coefficient & Estimate & Std. Error & $\operatorname{Pr}(>|\mathbf{t}|)$ & $\mathbf{2 . 5 \%}$ & $\mathbf{9 7 . 5 \%}$ & Adj. $\mathbf{R}^{\mathbf{2}}$ \\
\hline b0 & $3.973 \mathrm{e}^{+1}$ & $6.934 \mathrm{e}^{-1}$ & $<2 \mathrm{e}^{-16}$ & 38.34327 & 41.11725 & \\
b1 & $-8.364 \mathrm{e}^{-1}$ & $3.576 \mathrm{e}^{-2}$ & $<2 \mathrm{e}^{-16}$ & -0.90794 & -0.76489 & 0.922 \\
b2 & $4.739 \mathrm{e}^{-4}$ & $3.455 \mathrm{e}^{-5}$ & $<2 \mathrm{e}^{-16}$ & 0.00040 & 0.00054 & \\
\hline
\end{tabular}

Table 11. Results of the regression analysis and coefficient estimation - flexural strength $(\mathrm{fb}=6.489658$ $-0.123341 \times \mathrm{cr}+0.070092 \times$ slf $-0.003003 \times \mathrm{cr} \times$ slf).

\begin{tabular}{ccccccc}
\hline Coefficient & Estimate & Std. Error & $\operatorname{Pr}(>|\mathbf{t}|)$ & $\mathbf{2 . 5 \%}$ & $\mathbf{9 7 . 5 \%}$ & Adj. $\mathbf{R}^{\mathbf{2}}$ \\
\hline b0 & 6.48965 & 0.16031 & $<2 \mathrm{e}^{-16}$ & 6.16887 & 6.81044 & \\
b1 & -0.12334 & 0.00889 & $<2 \mathrm{e}^{-16}$ & -0.14113 & -0.10554 & 0.9372 \\
b2 & 0.07009 & 0.01860 & 0.00038 & 0.03286 & 0.10732 & \\
b3 & 0.00300 & 0.00103 & 0.00509 & 0.00093 & 0.00506 & \\
\hline
\end{tabular}

With estimated coefficients of the selected models, the relation between mechanical properties and the amount of crumb rubber and silica fume were presented graphically in Figures 15-17. 


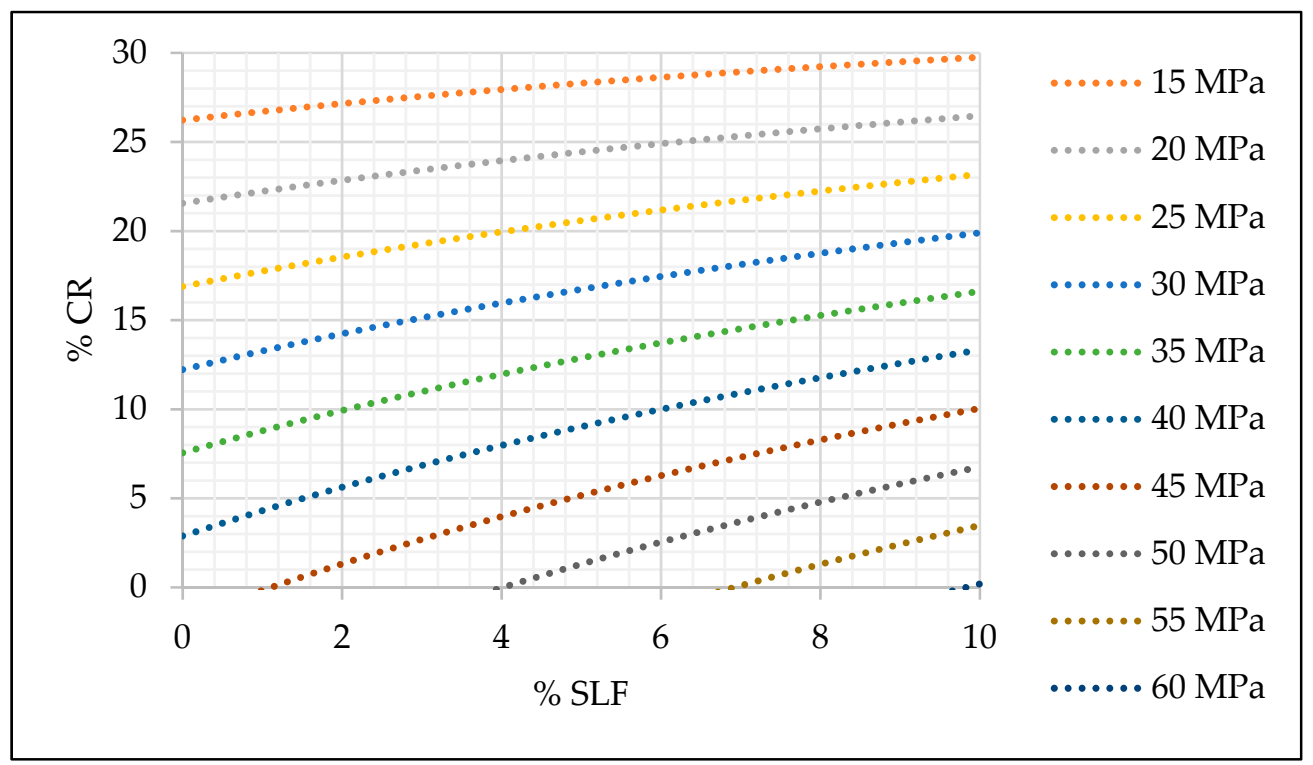

Figure 15. Prediction model for SCC compressive strength (fck $=43.09240-1,07104 \times \mathrm{cr}+1.72105 \times$ slf $-0.04515 \times \mathrm{cr} \times$ slf).

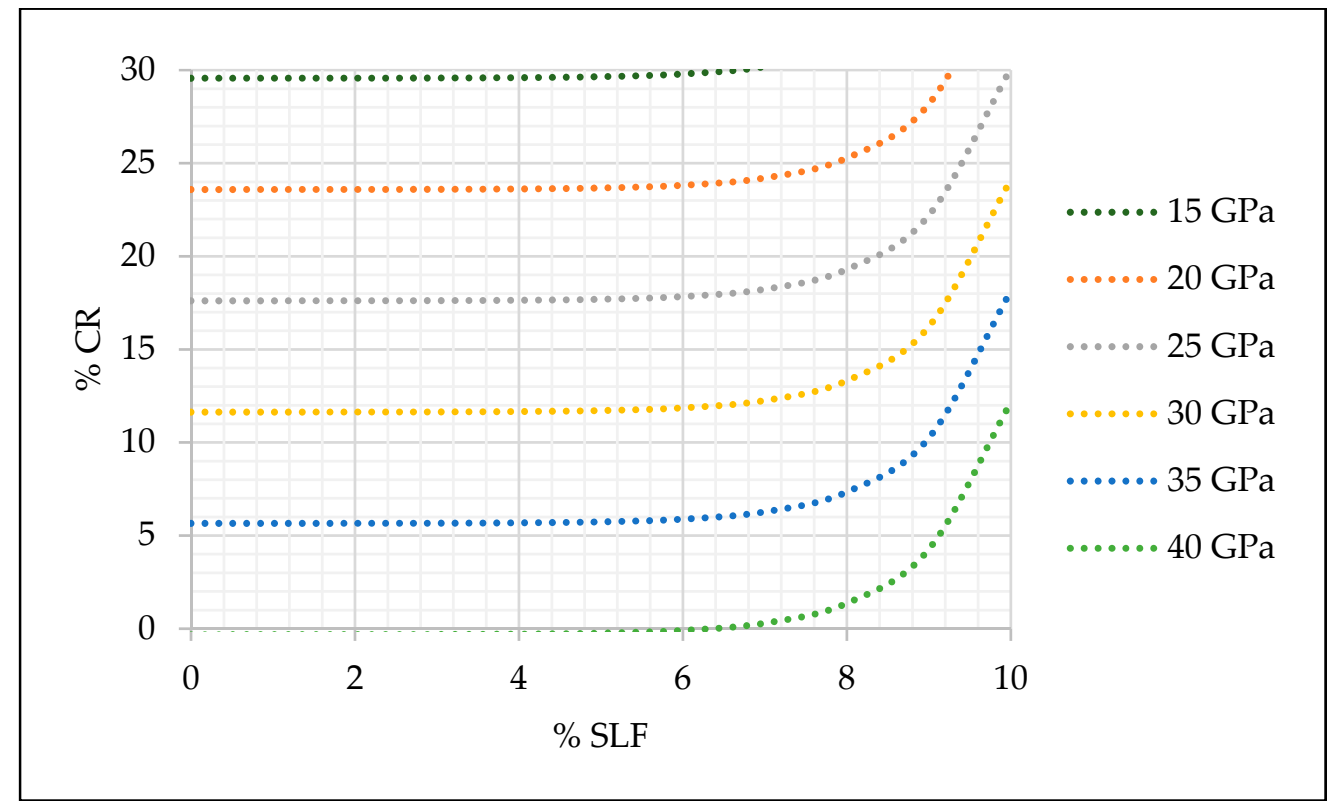

Figure 16. Prediction model for SCC modulus of elasticity $(E=39.7295-0.836401 \times c r+0.000473885$ $\times \exp (\mathrm{slf})$. 


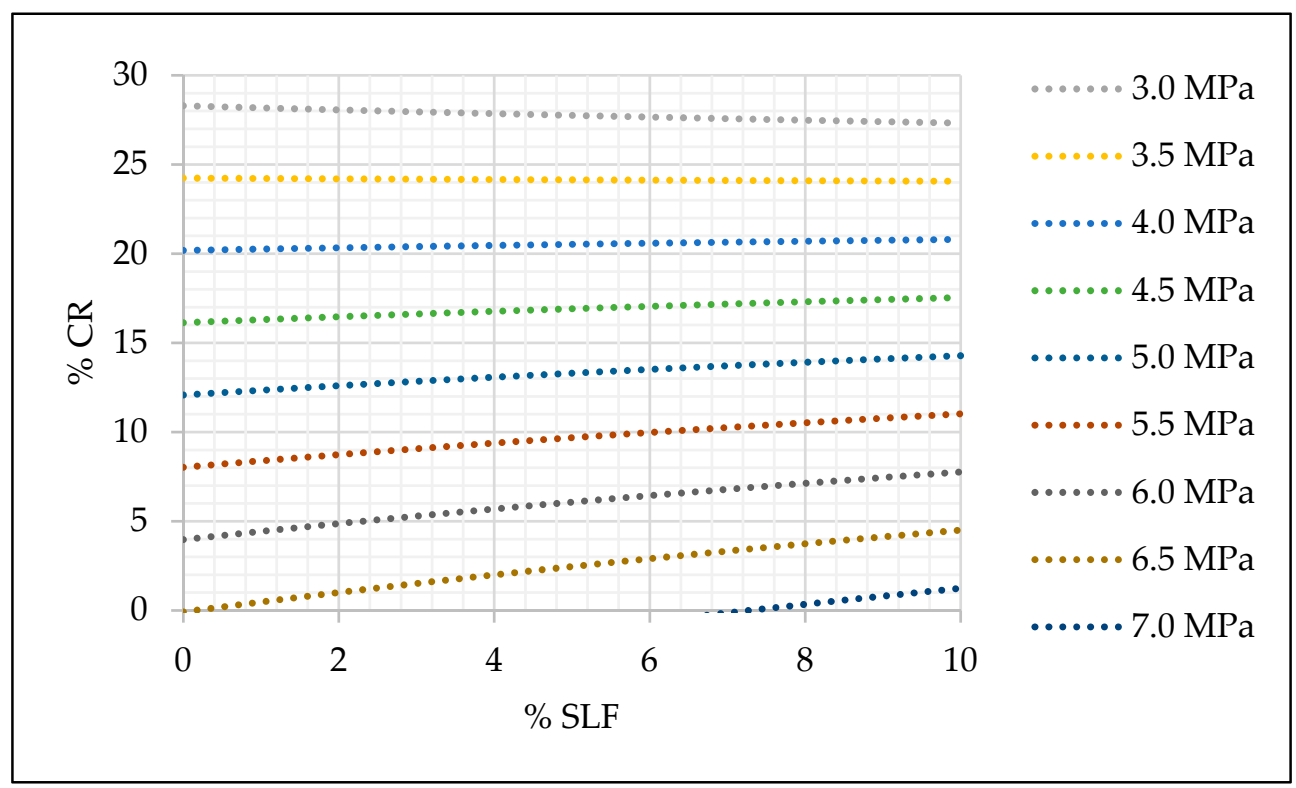

Figure 17. Prediction model for SCC flexural strength $(\mathrm{fb}=6.489658-0.123341 \times \mathrm{cr}+0.070092 \times$ slf $-0.003003 \times$ cr $\times$ slf).

For the chosen regression models, non-constant variance score tests (NCV test) were conducted [63], and they do not show the presence of heteroscedasticity. Furthermore, the Shapiro-Wilk test [64] did not suggest a deviation of standardized residuals from normality (p-values were $0.6533,0.4971$, and 0.1354 for regression models of compressive strength, modulus of elasticity, and flexural strength, respectively).

The practical application of prediction models and the graph given in Figures 15-17 can be simple, and it is explained as follows. According to the designed and required concrete class, engineers can easily select the replacement level of fine aggregate and cement and still maintain the desired concrete strength. For example, if a concrete compressive strength of $30 \mathrm{MPa}$ is required, $10 \%$ of fine aggregate replacement and $0 \%$ of cement replacement can be made. For the same concrete class, different percentage of replacement can be made, i.e., $15 \%$ of fine aggregate and $5 \%$ of silica fume.

The positive impact of silica fume on SCRC compressive strength, even with a minor replacement level of cement, can be seen from Figure 15. However, Figures 16 and 17 point to a slightly different conclusion where the impact of a minor replacement level of silica fume on the modulus of elasticity and flexural strength is questionable, and these replacement levels still need to be additionally investigated in order to investigate the influence of the smaller replacement levels of silica fume on these two mechanical properties of SCRC.

\subsection{Model Verification by Comparison with Other Experimental Studies}

In this section, 12 experimental studies from the literature are compared with the developed models: 7 for the compressive strength model $[5,6,11,42,43,65,66], 6$ for the modulus of elasticity model $[6,11,12,43,44,65]$, and 8 for the flexural strength model $[5,6,11,31,42,44,65,67]$. To avoid any unnecessary disagreements and inconsistencies with the proposed model, the results of experimental studies of other researchers were carefully selected as follows:

- Concrete type is SCC, not traditional concrete

- $\quad \mathrm{CR}$ is replacing FA, not $\mathrm{CA}$

- $\mathrm{CR}$ is replacing fine aggregate by total aggregate volume/fine aggregate volume, not by total aggregate weight/fine aggregate weight

- SLF is replacing cement by total cement mass, not by total powder/binder content

- Avoid experimental investigation with multiple supplementary cementitious material, such as combination of SLF and metakaolin, fly ash, or ground granulated blast furnace slag 
- $\quad$ Observed CR and SLF replacement level is 0-30\% and 0-10\%, respectively

- SCC compressive strength and modulus of elasticity is calculated from the experimental investigation of the cylinder specimen, whilst SCC flexural strength is calculated from the prism specimens, respectively.

As it was mentioned in Section 2, cement was replaced with SLF by total cement mass, while FA was replaced with CR by total aggregate volume. However, in all the experimental studies of the other researchers used for comparison, FA was replaced with CR by FA volume. Hence, to adjust the percentages of the replacement levels, a conversion coefficient needs to be applied on the CR percentage level in all cases where $\mathrm{CR}$ was used. This conversion coefficient can be easily obtained through a linear relationship of the FA by total aggregate volume (\%) and FA by FA volume (\%), which was used in model creation (Figure 18).

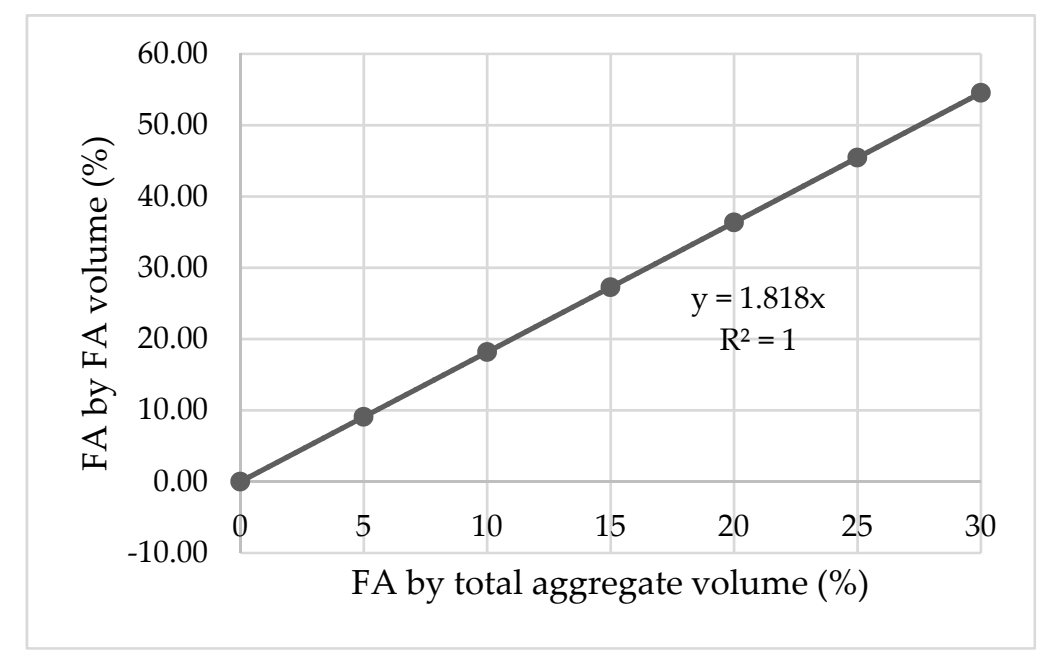

Figure 18. Conversion coefficient $(c=1 / 1.818=0.55)$.

Verification of the prediction models based on existing test results from the available literature is given in Tables 12-14 and Figure 19. The verifications of the developed models for the compressive strength and flexural strength yield good agreement with the experimental results of the other research studies. Ratio $\mathrm{f}_{\mathrm{ck}} / \mathrm{f}_{\mathrm{ck}}$, model obtained from 39 verification values has a range of values from 0.77 to 1.33 , with a total average of 1.03 and median of 1.05 . Ratio $\mathrm{f}_{\mathrm{b}} / \mathrm{f}_{\mathrm{b}}$, model obtained from 44 values has a range from 0.79 to 1.27 , with a total average of 0.97 and median of 0.91 . However, the verification of the developed model for the modulus of elasticity is a little less reliable than the other models. Ratio $\mathrm{E} / \mathrm{E}_{\text {model }}$ obtained from 30 values has a range from 0.7 to 0.97 , with a total average of 0.81 and median of 0.80 .

Table 12. Verification of the prediction model for the compressive strength $\left(f_{\mathrm{ck}}\right)$.

\begin{tabular}{ccccccc}
\hline Reference & CR $(\%)$ & $\mathbf{S L F}(\%)$ & CR after Conversion $(\%)$ & $\mathbf{f}_{\mathbf{c k}}(\mathbf{M P a})$ & $\mathbf{f}_{\text {ck,model }}(\mathbf{M P a})$ & $\mathbf{f}_{\mathbf{c k}} / \mathbf{f}_{\mathbf{c k}, \text { model }}$ \\
\hline & 0 & 0 & 0 & 52.95 & 43.09 & 1.23 \\
& 5 & 0 & 2.75 & 44.54 & 40.15 & 1.11 \\
& 10 & 0 & 5.50 & 42.09 & 37.20 & 1.13 \\
{$[6]$} & 15 & 0 & 8.25 & 37.35 & 34.26 & 1.09 \\
& 20 & 0 & 11.00 & 30.69 & 31.31 & 0.98 \\
& 25 & 0 & 13.75 & 28.83 & 28.36 & 1.02 \\
& 30 & 0 & 16.50 & 24.73 & 25.42 & 0.97 \\
& 20 & 0 & 11.00 & 32.81 & 31.31 & 1.05 \\
& 30 & 0 & 16.50 & 27.05 & 25.42 & 1.06 \\
\hline
\end{tabular}


Table 12. Cont.

\begin{tabular}{|c|c|c|c|c|c|c|}
\hline Reference & CR $(\%)$ & SLF (\%) & CR after Conversion (\%) & $\mathrm{f}_{\mathrm{ck}}(\mathrm{MPa})$ & $\mathrm{f}_{\mathrm{ck}, \text { model }}(\mathrm{MPa})$ & $\mathrm{f}_{\mathrm{ck}} / \mathrm{f}_{\mathrm{ck} \text {,model }}$ \\
\hline \multirow{8}{*}{ [5] } & 0 & 10 & 0 & 80.15 & 60.30 & 1.33 \\
\hline & 5 & 10 & 2.75 & 62.12 & 56.12 & 1.11 \\
\hline & 10 & 10 & 5.50 & 49.11 & 51.93 & 0.95 \\
\hline & 15 & 10 & 8.25 & 41.5 & 47.74 & 0.87 \\
\hline & 20 & 10 & 11.00 & 33.54 & 43.55 & 0.77 \\
\hline & 5 & 10 & 2.75 & 58.1 & 56.12 & 1.04 \\
\hline & 20 & 10 & 11.00 & 35.12 & 43.55 & 0.81 \\
\hline & 25 & 10 & 13.75 & 30.76 & 39.37 & 0.78 \\
\hline \multirow{7}{*}{ [11] } & 0 & 0 & 0 & 53.5 & 43.09 & 1.24 \\
\hline & 5 & 0 & 2.75 & 47.07 & 40.15 & 1.17 \\
\hline & 10 & 0 & 5.50 & 43.39 & 37.20 & 1.17 \\
\hline & 15 & 0 & 8.25 & 38.45 & 34.26 & 1.12 \\
\hline & 20 & 0 & 11.00 & 32.81 & 31.31 & 1.05 \\
\hline & 25 & 0 & 13.75 & 27.05 & 28.36 & 0.95 \\
\hline & 30 & 0 & 16.50 & 21.1 & 25.42 & 0.83 \\
\hline \multirow{3}{*}{ [65] } & 0 & 0 & 0 & 50.8 & 43.09 & 1.18 \\
\hline & 0 & 5 & 0 & 61.2 & 51.70 & 1.18 \\
\hline & 0 & 10 & 0 & 62.1 & 60.30 & 1.03 \\
\hline \multirow{6}{*}{ [42] } & 0 & 0 & 0 & 38.85 & 43.09 & 0.90 \\
\hline & 0 & 2 & 0 & 40.48 & 46.53 & 0.87 \\
\hline & 0 & 4 & 0 & 45.41 & 49.98 & 0.91 \\
\hline & 0 & 6 & 0 & 47.94 & 53.42 & 0.90 \\
\hline & 0 & 8 & 0 & 50.03 & 56.86 & 0.88 \\
\hline & 0 & 10 & 0 & 52.32 & 60.30 & 0.87 \\
\hline \multirow{4}{*}{ [66] } & 0 & 0 & 0 & 51.8 & 43.09 & 1.20 \\
\hline & 0 & 10 & 0 & 56.5 & 60.30 & 0.94 \\
\hline & 0 & 0 & 0 & 52.5 & 43.09 & 1.22 \\
\hline & 0 & 10 & 0 & 63.4 & 60.30 & 1.05 \\
\hline \multirow{2}{*}{ [43] } & 0 & 0 & 0 & 50.8 & 43.09 & 1.18 \\
\hline & 0 & 10 & 0 & 67.2 & 60.30 & 1.11 \\
\hline
\end{tabular}

Table 13. Verification of the prediction model for modulus of elasticity (E).

\begin{tabular}{|c|c|c|c|c|c|c|}
\hline Reference & CR (\%) & SLF (\%) & $\begin{array}{c}\text { CR after Conversion } \\
(\%)\end{array}$ & E (GPa) & $\mathrm{E}_{\text {model }}(\mathrm{GPa})$ & $\mathrm{E} / \mathrm{E}_{\text {model }}$ \\
\hline \multirow{9}{*}{ [6] } & 0 & 0 & 0 & 33.61 & 39.73 & 0.85 \\
\hline & 5 & 0 & 2.75 & 31.51 & 37.43 & 0.84 \\
\hline & 10 & 0 & 5.50 & 30.78 & 35.13 & 0.88 \\
\hline & 15 & 0 & 8.25 & 27.56 & 32.83 & 0.84 \\
\hline & 20 & 0 & 11.00 & 23.14 & 30.53 & 0.76 \\
\hline & 25 & 0 & 13.75 & 23.01 & 28.23 & 0.82 \\
\hline & 30 & 0 & 16.50 & 20 & 25.93 & 0.77 \\
\hline & 20 & 0 & 11.00 & 24.1 & 30.53 & 0.79 \\
\hline & 30 & 0 & 16.50 & 22.03 & 25.93 & 0.85 \\
\hline \multirow{7}{*}{ [11] } & 0 & 0 & 0 & 33.59 & 39.73 & 0.85 \\
\hline & 5 & 0 & 2.75 & 32.56 & 37.43 & 0.87 \\
\hline & 10 & 0 & 5.50 & 30.86 & 35.13 & 0.88 \\
\hline & 15 & 0 & 8.25 & 27.23 & 32.83 & 0.83 \\
\hline & 20 & 0 & 11.00 & 24.1 & 30.53 & 0.79 \\
\hline & 25 & 0 & 13.75 & 22.03 & 28.23 & 0.78 \\
\hline & 30 & 0 & 16.50 & 18.1 & 25.93 & 0.70 \\
\hline
\end{tabular}


Table 13. Cont.

\begin{tabular}{|c|c|c|c|c|c|c|}
\hline Reference & CR (\%) & SLF (\%) & $\begin{array}{c}\text { CR after Conversion } \\
(\%)\end{array}$ & E (GPa) & $\mathrm{E}_{\text {model }}(\mathrm{GPa})$ & $\mathrm{E} / \mathrm{E}_{\text {model }}$ \\
\hline \multirow{7}{*}[44]{} & 0 & 0 & 0 & 29.37 & 39.73 & 0.74 \\
\hline & 5 & 0 & 2.75 & 27.54 & 37.43 & 0.74 \\
\hline & 10 & 0 & 5.50 & 25.71 & 35.13 & 0.73 \\
\hline & 15 & 0 & 8.25 & 24.66 & 32.83 & 0.75 \\
\hline & 20 & 0 & 11.00 & 21.97 & 30.53 & 0.72 \\
\hline & 25 & 0 & 13.75 & 20.02 & 28.23 & 0.71 \\
\hline & 30 & 0 & 16.50 & 18.7 & 25.93 & 0.72 \\
\hline \multirow{3}{*}{ [65] } & 0 & 0 & 0 & 36.2 & 39.73 & 0.91 \\
\hline & 0 & 5 & 0 & 38.6 & 39.80 & 0.97 \\
\hline & 0 & 10 & 0 & 38.9 & 50.17 & 0.78 \\
\hline \multirow{2}{*}{ [12] } & 0 & 0 & 0 & 33 & 39.73 & 0.83 \\
\hline & 22.2 & 0 & 12.21 & 26.6 & 29.52 & 0.90 \\
\hline \multirow{2}{*}{ [43] } & 0 & 0 & 0 & 36.2 & 39.73 & 0.91 \\
\hline & 0 & 10 & 0 & 38.6 & 50.17 & 0.77 \\
\hline
\end{tabular}

Table 14. Verification of the prediction model for modulus of elasticity $\left(\mathrm{f}_{\mathrm{b}}\right)$.

\begin{tabular}{|c|c|c|c|c|c|c|}
\hline Reference & CR $(\%)$ & SLF (\%) & CR after Conversion (\%) & $\mathrm{f}_{\mathrm{b}}(\mathrm{MPa})$ & $\mathrm{f}_{\mathrm{b}, \text { model }}(\mathrm{MPa})$ & $\mathbf{f}_{\mathrm{b}} / \mathbf{f}_{\mathrm{b}, \text { model }}$ \\
\hline \multirow{3}{*}{ [31] } & 0 & 0 & 0 & 5.65 & 6.49 & 0.87 \\
\hline & 15 & 0 & 8.25 & 6.48 & 5.47 & 1.18 \\
\hline & 20 & 0 & 11.00 & 6.2 & 5.13 & 1.21 \\
\hline \multirow{9}{*}{ [6] } & 0 & 0 & 0 & 5.78 & 6.49 & 0.89 \\
\hline & 5 & 0 & 2.75 & 5.58 & 6.15 & 0.91 \\
\hline & 10 & 0 & 5.50 & 5.28 & 5.81 & 0.91 \\
\hline & 15 & 0 & 8.25 & 5.01 & 5.47 & 0.92 \\
\hline & 20 & 0 & 11.00 & 4.65 & 5.13 & 0.91 \\
\hline & 25 & 0 & 13.75 & 4.37 & 4.79 & 0.91 \\
\hline & 30 & 0 & 16.50 & 3.96 & 4.45 & 0.89 \\
\hline & 20 & 0 & 11.00 & 5 & 5.13 & 0.97 \\
\hline & 30 & 0 & 16.50 & 4.25 & 4.45 & 0.95 \\
\hline \multirow{7}{*}{ [5] } & 5 & 10 & 2.75 & 8.36 & 6.77 & 1.24 \\
\hline & 10 & 10 & 5.50 & 6.83 & 6.35 & 1.08 \\
\hline & 15 & 10 & 8.25 & 6.1 & 5.93 & 1.03 \\
\hline & 20 & 10 & 11.00 & 5.65 & 5.50 & 1.03 \\
\hline & 5 & 10 & 2.75 & 7.3 & 6.77 & 1.08 \\
\hline & 20 & 10 & 11.00 & 5.92 & 5.50 & 1.08 \\
\hline & 25 & 10 & 13.75 & 5.36 & 5.08 & 1.05 \\
\hline \multirow{7}{*}{ [11] } & 0 & 0 & 0 & 5.92 & 6.49 & 0.91 \\
\hline & 5 & 0 & 2.75 & 5.6 & 6.15 & 0.91 \\
\hline & 10 & 0 & 5.50 & 5.52 & 5.81 & 0.95 \\
\hline & 15 & 0 & 8.25 & 5.19 & 5.47 & 0.95 \\
\hline & 20 & 0 & 11.00 & 5 & 5.13 & 0.97 \\
\hline & 25 & 0 & 13.75 & 4.25 & 4.79 & 0.89 \\
\hline & 30 & 0 & 16.50 & 3.85 & 4.45 & 0.86 \\
\hline \multirow{7}{*}{ [44] } & 0 & 0 & 0 & 5.74 & 6.49 & 0.88 \\
\hline & 5 & 0 & 2.75 & 5.48 & 6.15 & 0.89 \\
\hline & 10 & 0 & 5.50 & 5.12 & 5.81 & 0.88 \\
\hline & 15 & 0 & 8.25 & 4.82 & 5.47 & 0.88 \\
\hline & 20 & 0 & 11.00 & 4.57 & 5.13 & 0.89 \\
\hline & 25 & 0 & 13.75 & 4.27 & 4.79 & 0.89 \\
\hline & 30 & 0 & 16.50 & 3.92 & 4.45 & 0.88 \\
\hline
\end{tabular}


Table 14. Cont.

\begin{tabular}{ccccccc}
\hline Reference & $\mathbf{C R}(\mathbf{\%})$ & $\mathbf{S L F}(\mathbf{\%})$ & $\mathbf{C R}$ after Conversion $\mathbf{( \% )}$ & $\left.\mathbf{f}_{\mathbf{b}} \mathbf{( M P a}\right)$ & $\mathbf{f}_{\mathbf{b}, \text { model }} \mathbf{( M P a )}$ & $\mathbf{f}_{\mathbf{b}} / \mathbf{f}_{\mathbf{b}, \text { model }}$ \\
\hline \multirow{2}{*}[65]{} & 0 & 0 & 0 & 8.2 & 6.49 & 1.26 \\
& 0 & 5 & 0 & 8.7 & 6.84 & 1.27 \\
& 0 & 10 & 0 & 8.8 & 7.19 & 1.22 \\
\hline \multirow{2}{*}[67]{} & 0 & 0 & 0 & 6.59 & 6.49 & 1.02 \\
& 0 & 5 & 0 & 6.59 & 6.84 & 0.96 \\
\hline \multirow{5}{*}[43]{} & 0 & 0 & 0 & 5.11 & 6.49 & 0.79 \\
& 0 & 2 & 0 & 5.61 & 6.63 & 0.85 \\
& 0 & 4 & 0 & 6.06 & 6.77 & 0.90 \\
& 0 & 6 & 0 & 6.22 & 6.91 & 0.90 \\
& 0 & 10 & 0 & 6.55 & 7.05 & 0.93 \\
\hline
\end{tabular}

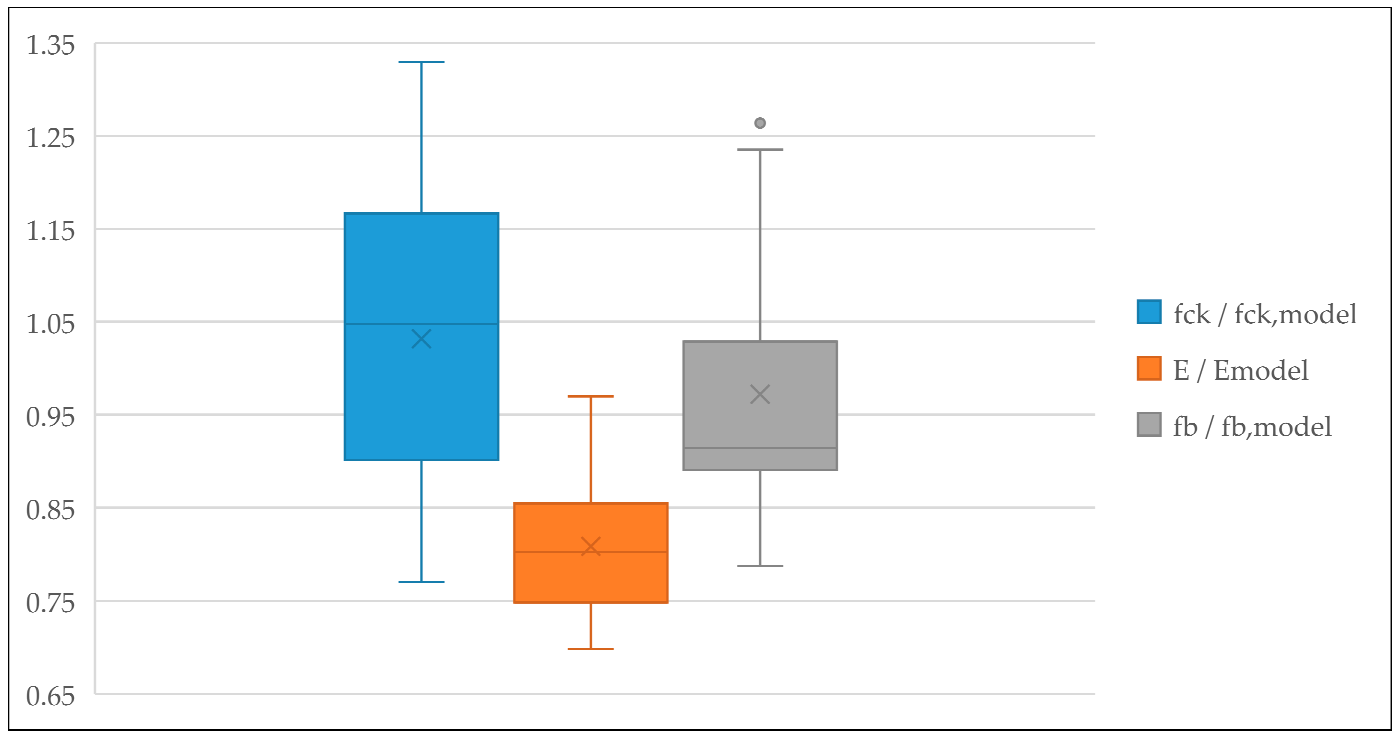

Figure 19. Verification of the prediction model—graphical interpretation.

In all three cases, factors that are possibly affecting the difference between experiment values and model values are listed as follows:

- Material properties (cement, aggregate, fillers, SCMs, recycled rubber, chemical admixtures, etc.)

- Mix proportions (w/b ratio, w/p ratio, binder content, SCMs content, FA to CA ratio, etc.)

- Mixing procedure and curing conditions (specimen preparation)

- Test methods (standards and specimen dimensions)

For future investigations and further development of the SCC model with SLF and CR, it can be suggested that additional laboratory work needs to be done, with a variation of more than two variables, such as $\mathrm{w} / \mathrm{b}$ ratio, binder content, cement type, etc. With additional variables included in the models, a larger database of the experimental results of the other researches can be used in the model verification process.

\section{Discussion}

In the present study, the fresh and hardened properties of SCC mixtures with different amounts of crumb rubber $(0-30 \%)$ and silica fume $(0-10 \%)$ were investigated. Furthermore, the test results of SCC in the hardened state were used for creation of the prediction models. Developed models were verified with 12 experimental studies. Several conclusions arise from the conducted experimental research and development of the statistical models: 
- An increase in the replacement level of fine aggregate with crumb rubber and cement with silica fume had a negative impact on the flowability of SCC mixtures; however, slump flow values were within acceptable limits for SCC mixtures with up to $25 \%$ of crumb rubber and $10 \%$ of silica fume.

- SCC mixtures with up to $15 \%$ of crumb rubber and up to $10 \%$ of silica fume can be classified as viscosity class VS1 $($ T500 $<2$ s).

- J-ring and L-box test results show a satisfactory passing ability of SCC mixture with up to $15 \%$ of crumb rubber and $10 \%$ of silica fume.

- Segregation was not present when $5 \%$ and $10 \%$ of cement was replaced with silica fume, but slight segregation was present in all mixtures without silica fume.

- A linear relationship between reduction in the dry unit weight and increase of replacement levels of natural fine aggregate with crumb rubber was observed.

- Considering the compressive strength of SCC, at a 30\% replacement level of fine aggregate with crumb rubber, silica fume can reduce the negative effect by up to $14 \%$.

- Values of the 28-day compressive strength of the SCC mixtures SCC-15CR-5SLF and SCC-10CR-0SLF were above $30 \mathrm{MPa}$, which can be taken into account if there is an intention for future investigation of self-compacting concrete on the structural elements and systems. Still, according to the obtained results, it can be suggested that the silica fume should be used in combination with recycled rubber only up to a $5 \%$ replacement level of the cement.

- Values of the 28-day modulus of elasticity were over $20 \mathrm{GPa}$ with a fine aggregate replacement level of up to $20 \%$.

- Replacing natural fine aggregate with crumb rubber also caused negative effects on the value of the flexural strength, but still at a smaller percentage compared to the compressive strength and modulus of elasticity.

- The positive impact of replacing cement with silica fume is more obvious for a lower replacement level of the natural fine aggregate with crumb rubber, i.e., up to $10 \%$.

- According to the developed model for the prediction of the compressive strength, with $10 \%$ and $15 \%$ of CR and $0 \%$ and $5 \%$ of SLF, a concrete compressive strength of $30 \mathrm{MPa}$ can be obtained.

- The verifications of the prediction models for the compressive strength and flexural strength give good agreement with the experimental results of the other research studies, while the prediction model for the modulus of elasticity is less reliable than that of the other two models.

- Values of the experiment/model ratio are affected by several factors such as the material properties, mix proportions, mixing procedure, and test methods.

\section{Conclusions}

The following are the overall conclusions drawn out of the obtained test results and observations made in this study:

- Favorable fresh and hardened SCC properties can be obtained with up to $15 \%$ of crumb rubber and $5 \%$ of silica fume.

- Models for the prediction of mechanical properties of SCC with crumb rubber and silica fume were developed and successfully verified.

- Future research directions:

- With an extensive laboratory work, create a database for defining an extended model with more than two variables included, such as the w/b ratio, binder content, cement type etc.

- Detailed analysis of the durability, thermal, long-term and micro-level properties (SEM) needs to be done, and thereafter full-scale models of SCRC beams, columns, and frames with selected optimal SCC mixtures need to be investigated. 
Author Contributions: Conceptualization, R.B., I.M., and M.B.; methodology, R.B. and I.M.; investigation, R.B. and K.S.; resources, R.B. and I.M.; writing-original draft preparation, R.B.; writing-review and editing, R.B., I.M., and M.B.; visualization, R.B.; supervision, M.B. and I.M.; project administration, R.B. and I.M.; funding acquisition, I.M. All authors have read and agreed to the published version of the manuscript.

Funding: This paper was supported by Croatian Science Foundation under project UIP-2017-05-7113 Development of Reinforced Concrete Elements and Systems with Waste Tire Powder - ReCoTiP.

Conflicts of Interest: The authors declare no conflict of interest.

\section{References}

1. Moustafa, A.; ElGawady, M.A. Mechanical properties of high strength concrete with scrap tire rubber. Constr. Build. Mater. 2015, 93, 249-256. [CrossRef]

2. Si, R.; Wang, J.; Guo, S.; Dai, Q.; Han, S. Evaluation of laboratory performance of self-consolidating concrete with recycled tire rubber. J. Clean. Prod. 2018, 180, 823-831. [CrossRef]

3. Murugan, R.B.; Sai, E.R.; Natarajan, C.; Chen, S.-E. Flexural fatigue performance and mechanical properties of rubberized concrete. Gradjevinar 2017, 69, 983-990.

4. Jedidi, M.; Gargouri, A.; Daoud, A. Effect of Rubber Aggregates on the Thermophysical Properties of Self-Consolidating Concrete. Int. J. Therm. Environ. Eng. 2014, 8, 1-7. [CrossRef]

5. Abdelaleem, B.H.; Hassan, A.A. Development of self-consolidating rubberized concrete incorporating silica fume. Constr. Build. Mater. 2018, 161, 389-397. [CrossRef]

6. Ismail, M.K.; Hassan, A.A.A. Use of metakaolin on enhancing the mechanical properties of self-consolidating concrete containing high percentages of crumb rubber. J. Clean. Prod. 2016, 125, 282-295. [CrossRef]

7. Uygunoğlu, T.; Topçu, I.B. The role of scrap rubber particles on the drying shrinkage and mechanical properties of self-consolidating mortars. Constr. Build. Mater. 2010, 24, 1141-1150. [CrossRef]

8. Abdelaleem, B.H.; Ismail, M.K.; Hassan, A.A. The combined effect of crumb rubber and synthetic fibers on impact resistance of self-consolidating concrete. Constr. Build. Mater. 2018, 162, 816-829. [CrossRef]

9. Najim, K.; Hall, M. Mechanical and dynamic properties of self-compacting crumb rubber modified concrete. Constr. Build. Mater. 2012, 27, 521-530. [CrossRef]

10. Turatsinze, A.; Garros, M. On the modulus of elasticity and strain capacity of Self-Compacting Concrete incorporating rubber aggregates. Resour. Conserv. Recycl. 2008, 52, 1209-1215. [CrossRef]

11. Ismail, M.K.; de Grazia, M.T.; Hassan, A.A.A. Mechanical Properties of Self-Consolidating Rubberized Concrete with Different Supplementary Cementing Materials. In Proceedings of the International Conference on Transportation and Civil Engineering (ICTCE'15), London, UK, 21-22 March 2015; pp. 68-74.

12. Bignozzi, M.; Sandrolini, F. Tyre rubber waste recycling in self-compacting concrete. Cem. Concr. Res. 2006, 36, 735-739. [CrossRef]

13. Aslani, F.; Ma, G.; Wan, D.L.Y.; Muselin, G. Development of high-performance self-compacting concrete using waste recycled concrete aggregates and rubber granules. J. Clean. Prod. 2018, 182, 553-566. [CrossRef]

14. Hall, M.; Najim, K. Structural behaviour and durability of steel-reinforced structural Plain/Self-Compacting Rubberised Concrete (PRC/SCRC). Constr. Build. Mater. 2014, 73, 490-497. [CrossRef]

15. Ismail, M.K.; Hassan, A.A.A. Performance of Full-Scale Self-Consolidating Rubberized Concrete Beams in Flexure. ACI Mater. J. 2016, 113, 207-218. [CrossRef]

16. Ismail, M.K.; Hassan, A.A. Shear behaviour of large-scale rubberized concrete beams reinforced with steel fibres. Constr. Build. Mater. 2017, 140, 43-57. [CrossRef]

17. Vadivel, T.S.; Thenmozhi, R.; Doddurani, M. Experimental behaviour of waste tyre rubber aggregate concrete under impact loading. Iran. J. Sci. Technol.-Trans. Civ. Eng. 2014, 38, 251-259.

18. Gesoglu, M.; Güneyisi, E.; Khoshnaw, G.; Ipek, S. Investigating properties of pervious concretes containing waste tire rubbers. Constr. Build. Mater. 2014, 63, 206-213. [CrossRef]

19. Youssf, O.; ElGawady, M.A.; Mills, J.E.; Ma, X. An experimental investigation of crumb rubber concrete confined by fibre reinforced polymer tubes. Constr. Build. Mater. 2014, 53, 522-532. [CrossRef]

20. Zheng, L.; Huo, X.S.; Yuan, Y. Strength, Modulus of Elasticity, and Brittleness Index of Rubberized Concrete. J. Mater. Civ. Eng. 2008, 20, 692-699. [CrossRef]

21. Elghazouli, A.Y.; Bompa, D.V.; Xu, B.; Ruiz-Teran, A.; Stafford, P. Performance of rubberised reinforced concrete members under cyclic loading. Eng. Struct. 2018, 166, 526-545. [CrossRef] 
22. Gesoglu, M.; Güneyisi, E.; Hansu, O.; Ipek, S.; Asaad, D.S. Influence of waste rubber utilization on the fracture and steel-concrete bond strength properties of concrete. Constr. Build. Mater. 2015, 101, 1113-1121. [CrossRef]

23. Zhu, X.; Miao, C.; Liu, J.; Hong, J. Influence of Crumb Rubber on Frost Resistance of Concrete and Effect Mechanism. Procedia Eng. 2012, 27, 206-213. [CrossRef]

24. Richardson, A.; Coventry, K.; Ward, G. Freeze/thaw protection of concrete with optimum rubber crumb content. J. Clean. Prod. 2012, 23, 96-103. [CrossRef]

25. Richardson, A.; Coventry, K.; Edmondson, V.; Dias, E. Crumb rubber used in concrete to provide freeze-thaw protection (optimal particle size). J. Clean. Prod. 2016, 112, 599-606. [CrossRef]

26. Liu, H.; Wang, X.; Jiao, Y.; Sha, T. Experimental Investigation of the Mechanical and Durability Properties of Crumb Rubber Concrete. Materials 2016, 9, 172. [CrossRef]

27. Gesoglu, M.; Güneyisi, E.; Khoshnaw, G.; Ipek, S. Abrasion and freezing-thawing resistance of pervious concretes containing waste rubbers. Constr. Build. Mater. 2014, 73, 19-24. [CrossRef]

28. Moustafa, A.; ElGawady, M. Dynamic Properties of High Strength Rubberized Concrete; ACI Special Publication: Indianapolis, IN, USA, 2017; pp. 33-54.

29. Bideci, A.; Öztürk, H.; BideciÖzlem, S.; Emiroğlu, M. Fracture energy and mechanical characteristics of self-compacting concretes including waste bladder tyre. Constr. Build. Mater. 2017, 149, 669-678. [CrossRef]

30. Grinys, A.; Sivilevičius, H.; Pupeikis, D.; Ivanauskas, E. Fracture of concrete containing crumb rubber. J. Civ. Eng. Manag. 2013, 19, 447-455. [CrossRef]

31. Ganesan, N.; Raj, J.B.; Shashikala, A. Flexural fatigue behavior of self compacting rubberized concrete. Constr. Build. Mater. 2013, 44, 7-14. [CrossRef]

32. Najim, K.; Hall, M. Crumb rubber aggregate coatings/pre-treatments and their effects on interfacial bonding, air entrapment and fracture toughness in self-compacting rubberised concrete (SCRC). Mater. Struct. 2013, 46, 2029-2043. [CrossRef]

33. Bušić, R.; Miličević, I.; Šipoš, T.K.; Strukar, K. Recycled Rubber as an Aggregate Replacement in Self-Compacting Concrete-Literature Overview. Materials 2018, 11, 1729. [CrossRef] [PubMed]

34. Strukar, K.; Šipoš, T.K.; Miličević, I.; Bušić, R. Potential use of rubber as aggregate in structural reinforced concrete element - A review. Eng. Struct. 2019, 188, 452-468. [CrossRef]

35. Najim, K.; Hall, M. A review of the fresh/hardened properties and applications for plain- (PRC) and self-compacting rubberised concrete (SCRC). Constr. Build. Mater. 2010, 24, 2043-2051. [CrossRef]

36. Guo, Z.; Jiang, T.; Zhang, J.; Kong, X.; Chen, C.; Lehman, D.E. Mechanical and durability properties of sustainable self-compacting concrete with recycled concrete aggregate and fly ash, slag and silica fume. Constr. Build. Mater. 2020, 231, 117115. [CrossRef]

37. Falmata, A.M.; Sulaiman, A.; Mohamed, R.N.; Shettima, A.U. Mechanical properties of self-compacting high-performance concrete with fly ash and silica fume. SN Appl. Sci. 2019, 2, 33. [CrossRef]

38. Nasr, D.; Behforouz, B.; Borujeni, P.R.; Borujeni, S.A.; Zehtab, B. Effect of nano-silica on mechanical properties and durability of self-compacting mortar containing natural zeolite: Experimental investigations and artificial neural network modeling. Constr. Build. Mater. 2019, 229, 116888. [CrossRef]

39. Meng, W.; Valipour, M.; Khayat, K.H. Optimization and performance of cost-effective ultra-high performance concrete. Mater. Struct. 2017, 50, 29. [CrossRef]

40. Meng, W.; Khayat, K.H. Mechanical properties of ultra-high-performance concrete enhanced with graphite nanoplatelets and carbon nanofibers. Compos. Part B Eng. 2016, 107, 113-122. [CrossRef]

41. Salehi, H.; Mazloom, M. Opposite effects of ground granulated blast-furnace slag and silica fume on the fracture behavior of self-compacting lightweight concrete. Constr. Build. Mater. 2019, 222, 622-632. [CrossRef]

42. Ahmad, S.; Umar, A.; Masood, A.; Nayeem, M. Performance of self-compacting concrete at room and after elevated temperature incorporating Silica fume. Adv. Concr. Constr. 2019, 7, 31-37. [CrossRef]

43. Benaicha, M.; Belcaid, A.; Alaoui, A.H.; Jalbaud, O.; Burtschell, Y. Effects of limestone filler and silica fume on rheology and strength of self-compacting concrete. Struct. Concr. 2019, 20, 1702-1709. [CrossRef]

44. Ismail, M.K.; Hassan, A.A.A. Impact Resistance and Mechanical Properties of Self-Consolidating Rubberized Concrete Reinforced with Steel Fibers. J. Mater. 2016, 29, 04016193. [CrossRef]

45. The European Guidelines for Self-Compacting Concrete. Available online: https://www.theconcreteinitiative. eu/images/ECP_Documents/EuropeanGuidelinesSelfCompactingConcrete.pdf (accessed on 10 January 2020). 
46. European Committee for Standardization (CEN). EN 197-1:2012 Cement_Part 1: Composition, Specifications and Conformity Criteria for Common Cements; CEN: Brussels, Belgium, 2012.

47. European Committee for Standardization (CEN). EN 13263-1:2009: Silica Fume for Concrete_Part 1: Definitions, Requirements and Conformity Criteria; CEN: Brussels, Belgium, 2009.

48. European Committee for Standardization (CEN). EN 1008:2002 Mixing Water for Concrete—Specification for Sampling, Testing and Assessing the Suitability of Water, Including Water Recovered from Processes in the Concrete Industry, as Mixing Water for Concrete; CEN: Brussels, Belgium, 2002.

49. European Committee for Standardization (CEN). EN 934-1:2008: Admixtures for Concrete, Mortar and Grout_Part 1: Common Requirements; CEN: Brussels, Belgium, 2008.

50. European Committee for Standardization (CEN). EN 934-2:2012: Admixtures for Concrete, Mortar and Grout_Part 2: Concrete Admixtures-Definitions, Requirements, Conformity, Marking and Labelling; CEN: Brussels, Belgium, 2012.

51. ASTM, C188-16. Standard Test Method for Density of Hydraulic Cement; ASTM International: West Conshohocken, PA, USA, 2011; Volume 95, pp. 37-39. [CrossRef]

52. European Committee for Standardization (CEN), EN 933-1:2012: Tests for Geometrical Properties of Aggregates-Part 1: Determination of Particle Size Distribution—Sieving Method; CEN: Brussels, Belgium, 2012.

53. European Committee for Standardization (CEN). EN 12350-12:2010: Testing Fresh Concrete-Part 12: Self-Compacting Concrete-J-Ring Test; CEN: Brussels, Belgium, 2010.

54. European Committee for Standardization (CEN). EN 12350-10:2010: Testing Fresh Concrete-Part 10: Self-Compacting Concrete - L Box Test; CEN: Brussels, Belgium, 2010.

55. European Committee for Standardization (CEN). EN 12350-8:2010: Testing Fresh Concrete-Part 8: Self-Compacting Concrete-Slump Flow Test; CEN: Brussels, Belgium, 2010.

56. European Committee for Standardization (CEN). EN 12350-11:2010: Testing Fresh Concrete-Part 11: Self-compacting Concrete-Sieve Segregation Test; CEN: Brussels, Belgium, 2010.

57. European Committee for Standardization (CEN). EN 12390-3:2009: Testing Hardened Concrete-Part 3: Compressive Strength of Test Specimens; CEN: Brussels, Belgium, 2009.

58. European Committee for Standardization (CEN). EN 12390-5:2009: Testing Hardened Concrete-Part 5: Flexural Strength of Test Specimens; CEN: Brussels, Belgium, 2009.

59. European Committee for Standardization (CEN). EN 12390-13:2013: Testing Hardened Concrete-Part 13: Determination of Secant Modulus of Elasticity in Compression; CEN: Brussels, Belgium, 2013.

60. Rahman, M.; Usman, M.; Al-Ghalib, A.A. Fundamental properties of rubber modified self-compacting concrete (RMSCC). Constr. Build. Mater. 2012, 36, 630-637. [CrossRef]

61. Topçu, I.B.; Bilir, T. Experimental investigation of some fresh and hardened properties of rubberized self-compacting concrete. Mater. Des. 2009, 30, 3056-3065. [CrossRef]

62. Aslani, F.; Ma, G.; Wan, D.L.Y.; Le, V.X.T. Experimental investigation into rubber granules and their effects on the fresh and hardened properties of self-compacting concrete. J. Clean. Prod. 2018, 172, 1835-1847. [CrossRef]

63. Breusch, T.S.; Pagan, A.R. A Simple Test for Heteroscedasticity and Random Coefficient Variation. Econometrica 1979, 47, 1287. [CrossRef]

64. Shapiro, S.S.; Wilk, M.B. An analysis of variance test for normality (complete samples). Biometrika 1965, 52, 591-611. [CrossRef]

65. Benaicha, M.; Roguiez, X.; Jalbaud, O.; Burtschell, Y.; Alaoui, A.H. Influence of silica fume and viscosity modifying agent on the mechanical and rheological behavior of self compacting concrete. Constr. Build. Mater. 2015, 84, 103-110. [CrossRef]

66. Jalal, M.; Pouladkhan, A.; Harandi, O.F.; Jafari, D. Comparative study on effects of Class F fly ash, nano silica and silica fume on properties of high performance self compacting concrete. Constr. Build. Mater. 2015, 94, 90-104. [CrossRef]

67. Dehwah, H. Mechanical properties of self-compacting concrete incorporating quarry dust powder, silica fume or fly ash. Constr. Build. Mater. 2012, 26, 547-551. [CrossRef]

(C) 2020 by the authors. Licensee MDPI, Basel, Switzerland. This article is an open access article distributed under the terms and conditions of the Creative Commons Attribution (CC BY) license (http://creativecommons.org/licenses/by/4.0/). 